\title{
EFFECTS OF INTACT LOOP HYDRAULIC RESISTANCE OF PWR LOCA BEHAVIOR IN SCALED EXPERIMENTAL FACILITIES
}

MARSHALL S. JACOBY

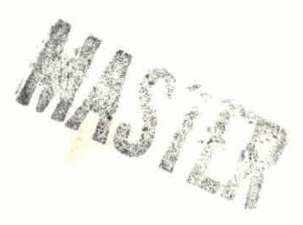

September 1977

EGEG Idaho, Inc.

IDAHO NATIONAL ENGINEERING LABORATORY

\section{DEPARTMENT OF ENERGY}

IDAHO OPERATIONS OFFICE UNDER CONTRACT EY-76-C-07-1570 


\section{DISCLAIMER}

This report was prepared as an account of work sponsored by an agency of the United States Government. Neither the United States Government nor any agency Thereof, nor any of their employees, makes any warranty, express or implied, or assumes any legal liability or responsibility for the accuracy, completeness, or usefulness of any information, apparatus, product, or process disclosed, or represents that its use would not infringe privately owned rights. Reference herein to any specific commercial product, process, or service by trade name, trademark, manufacturer, or otherwise does not necessarily constitute or imply its endorsement, recommendation, or favoring by the United States Government or any agency thereof. The views and opinions of authors expressed herein do not necessarily state or reflect those of the United States Government or any agency thereof. 


\section{DISCLAIMER}

Portions of this document may be illegible in electronic image products. Images are produced from the best available original document. 
Printed in the United States of America Available from

National Technical Information Service

U.S. Department of Commerce

5285 Port Royal Road

Springfield, Virginia 22161

Price: Printed Copy $\$ 4.50$; Microfiche $\$ 3.00$

"The NRC will make available data tapes and operational computer codes on research programs dealing with postulated loss-of-coolant accidents in light water reactors. Persons requesting this information must reimburse the NRC contractors for their expenses in preparing copies of the data tapes and the operational computer codes. Requests should be submitted to the Research Applications Branch, Office of Nuclear Regulatory Research, Nuclear Regulatory Commission, Washington, D.C. 20555."

\section{NOTICE}

This report was prepared as an account of work sponsored by the United States Government. Neither the the United States nor the Department of Energy, nor the Nuclear Regulatory Commission, nor any of their employees, nor any of their contractors, subcontractors, or their employees, makes any warranty, express or implied, or assumes any legal liability or responsibility for the accuracy, completeness or usefulness of any information, apparatus, product or process disclosed, or represents that its use would not infringe privately owned rights. 
EFFECTS OF INTACT LOOP HYDRAULIC RESISTANCE OF PWR LOCA BEHAVIOR IN

SCALED EXPERIMENTAL FACILITIES

WOTICE

report was prepared as an account of work ponsored by the United States Govemment. Neither the United United States Department of Energ. nor any of their employees, nor any of their contractors, subcontractors, or their employees, makes any, warranty, express or implied, or assumes any legal lability or responsibility for the accuracy, completeness or usefulnass of any infurmation, apparatus, product of process disclosed, or represents that its use would not infringe privately owned rights.

\section{Approved:}

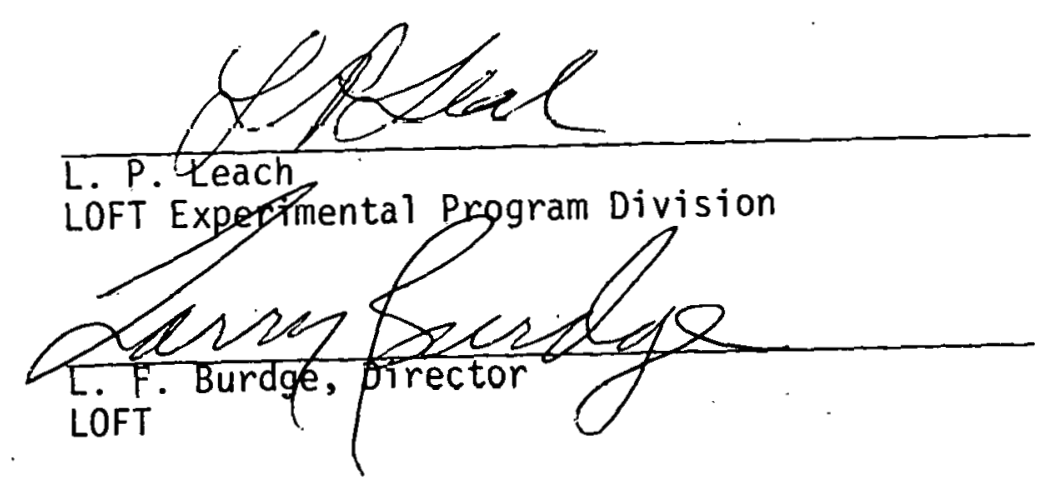




\section{EFFECTS OF INTACT LOOP HYDRAULIC RESISTANCE OF PWR LOCA BEHAVIOR IN \\ SCALED EXPERIMENTAL FACILITIES}

by

Marshal1 S. Jacoby

EG\&G Idaho, Inc.

September 1977

PREPARED FOR THE

U.S. NUCLEAR REGULATORY COMMISSION AND

ENERGY RESEARCH AND DEVELOPMENT ADMINISTRATION

UNDER CONTRACT NO. EY-76-C-07-1570 


\section{ABSTRACT}

Experiments and analyses of the blowdown and reflood behavior of scaled model systems are examined for the effects of variation of intact loop hydraulic resistance. No significant effects could be found. 


\section{SUMMARY}

The scaling of experiments in the Water Reactor Safety Program has been on a power/volume basis. This scaling philosophy has resulted in good thermal modeling of the core, but, combined with core design considerations, compromises the-modeling of the hydraulic resistance in the intact loop. Tests in LOFT, Semiscale MOD- 1 and FLECHT-SET have been conducted for the purpose of determining the effect of scaling hydraulic resistance to core area ratio (low hydraulic resistance) or to core power ratio (high hydraulic resistance). The results of these tests, together with computer model results using RELAP4/MOD5, RE-FRAP, and FLOOD4, were studied to determine the effects of the scaling compromise. The review of available information has shown no significant results of varying. intact loop hydraulic resistance. 
ABSTRACT .................................

SUMMARY. . . . .......................... . .

I. INTRODUCTION . . . . . . . . . . . . . . . . . . . I

I I.

1. LOFT Blowdown Analysis............... . . . 5

1.1 LOFT RELAP/MOD5 System.Mode1........... 5

1.2 LOFT RE-FRAP Modcl. . . . . . . . . . . . . . . . . 7

1.3 Resul ls of LOFT Blowduwn Calculations

with RE-FRAP. . . . . . . . . . . . . 7

2. LOFT REFLOOD Analysis. . . . . . . . . . . . 14

2.1 LOFT FLOOD4 Model . . . . . . . . . . . . 17

2.2 .LOFT FLOOD4 Results ... . . . . . . . . . . 17

III. EXPERIMENTS . . . . . . . . . . . . . . . . . . . . 21

1. LOFT Isothermal Blowdown Tests System Configuration. . . 21

2. LOFT Experimental Results. . . . . . . . . . . .. 22

3. Semiscale Isothermal Blowdown and -REFLOOD Tes.ts. . . . . 27

4. Semiscale MOD-1 Isothermal Blowdown Test Description . . 28

5. Isothermal Test Results. ... . . . . . ... 28

6. Semiscale Mod-1 REFLnOn Test Desoription . . . . . . . . 29

7. Results of Semiscale RLl-LUUU lesting . . . . . . . . . 34

8. FLECHT-SET Experiment. . ............... . 36

8.1 Results of FLECHT-SET REFLOOD Experiments . . . . 37

IV. CONCLUSIONS . . . . . . . . . . . . . . . . . . . . . . 39

V. REFERENCES. . . . . . . . . . . . . . . . . . . . . . 40

FIGURES

1. Resistance network for core flooding. . . . . . . . . . . 3 
2. LOFT RELAP nodalization ............ . . 6

3. Schematic of hot pin model. . . . . . . . . . 8

4. Density -- average core RELAP model. . . . . . . . . 9

5. Cold leg intact loop resistance -- average core
LOFT RELAP model. . . . . . . . . . 10

6. Density response average core -- LOFT RELAP model ...... . ו ו

7. Hot leg intact loop flow response -- average core
LOFT RELAP model. . . . . . . . . 12

8. Downcomer flow response -- average core LOFT RELAP model. . 13

9. Downcomer density response -- average core LOFT RELAP model. ................ . . 13

10. Average hot spot quality -- hot pin LOFT RE-FRAP model. . . 14

11. Lower plenum flow response -- hot pin LOFT RE-FRAP model. . 15

12. Clad temperature response -- hot pin LOFT RE-FRAP model . . 16

13. Sketch of FLOOD-4 model ............. . 18

14. Fuel rod nodalization for LOFT FLOOD-4 model. . . . . . . 19

15. Clad temperature response -- LOFT FLOOD-4 mode1 . . . . 20

16. Major LOFT components . . . . . . . . . . . . 23

17. LOFT pressure response -- LOFT isothermal blowdown. . . . . 25

18. Downcomer fluid temperature -- LOFT isothermal blowdown .. . 26'

19. Upper plcnum prossurc response -- Semiscale isothermal blowdown ................ 30

20. Intact loop hot leg density response -- Semiscale isothermal test................... 30

21. Cold leg intact loop mass flow response -- Semiscale isothermal blowdown ............... 31

22. Core inlet mass flow response -- Semiscale isothermal test................ 32

23. Semiscale vessel cross section and core layout. . . . . 33

24. Temperature response at the 29-in. elevation -- Semiscale REFLnOn test.s..................... 35 
25. Core inlet flooding rate -- Semiscale REFLOOD tests . . . . 35

26. Core inlet integrated mass flow rate -- Semiscale gravity REFLOOD tests................... 36 


\section{INTRODUCTION}

The relationship between the relative magnitude of the hydraulic resistance in the three intact loops of a large pressurized water reactor (LPWR) and the behavior of the reactor system under loss-ofcoolant accident ( $L O C A$ ) conditions will be explored by the examination of experimental and analytical results of scaled systems. The primary source of model data will be the Loss-of-fluid Test (LOFT) facility. The LOFT Program is part of the Water Reactor Safety Research Program sponsored by the Nuclear Regulatory Commission and is administered by the Energy Research and Development Administration. The tests are conducted at the Idaho National Engineering Laboratory (INEL), Test Area North (TAN). The objectives of the program are:

(1) To provide data required to evaluate the adequacy and improve the analytical methods currently used to predict the LOCA response of LPWRs. The performance of engineered safety features (ESF) with particular emphasis on emergency core cooling system (ECCS) and the quantitative margins of safety inherent in the performance of ESF are of priamry interest.

(2) To identify and investigate any unexpected event(s) or threshold(s) in the response of either the plant or the ESF, and develop analytical techniques that adequately describe and account for such unexpected behavior.

In order to meet these objectives, the LOFT Integral Test facility ${ }^{[a]}$ has been designed to simulate the major components of a

[a] The term "integral" is used to describe an experiment combining the nuclear, thermal, hydraulic, and structural processes occurring during a LOCA and differentiates it from the separate effects, nonnuclear, smal1-scale, thermo-hydraulic experiments conducted for loss-of-coolant analysis. 
LPWR, and several series of experiments have been planned to produce data on the combined thermal, hydraulic, nuclear, and structural processes expected to occur during a LOCA.

The effect of intact. loop hydraulic resistance is an important consideration in determining the method of scaling for the blowdown and reflood phases of a simulated LOCA ${ }^{[1]}$. Scaling of the LOFT test apparatus is on a volume to power basis. The advantage of this type of scaling is it ensures the same relative amount of fluid is available for energy exchange in LOFT as in the LPWR. Also, the time scale can be preserved by controlling the system break size. The thermo-hydraulic phenomena therefore occur in LOFT and LPWRs in the same time frame all of which are important during blowdown.

However, core design requirements together with heat transfer requirements dictated a shorter than ideal core. The use of volumetric scaling produces a piping and core area which is about twice for a core length which is about half the respective ideal value ${ }^{[1]}$. Thus, the flow resistance for the core and piping is not the ideal value. The piping resistance, in particular, is a strong tunction of area; it then becomes necessary to place orifices in the piping to adjust the resistance to the desired values which can be based upun either power ratio scaling to preserve the blowdown hydraulic phenomena and intact loop initial conditions or on core area scaling which can preserve reflood hydraulic phenomena.

The core area scaling, which is a low resistance scaling, preserves reflood hydraulic phenomena because the ratio of system resistances through relative flow paths would have the same ratio as a LPWR. This effect can be seen by considering the resistance network (Figure 1). If the steam generator hydraulic resistance were scaled according to the volume/power relationship, it would be high with respect to the core hydraulic resistance. Less flow would tend to go through the intact loop in the normal direction which would cause increased back pressure at the vessel outlet and a tendency for emergency core coolant (ECC) to bypass the vessel. It can be seen also that the broken loop hydraulic 
Intact loop (s)

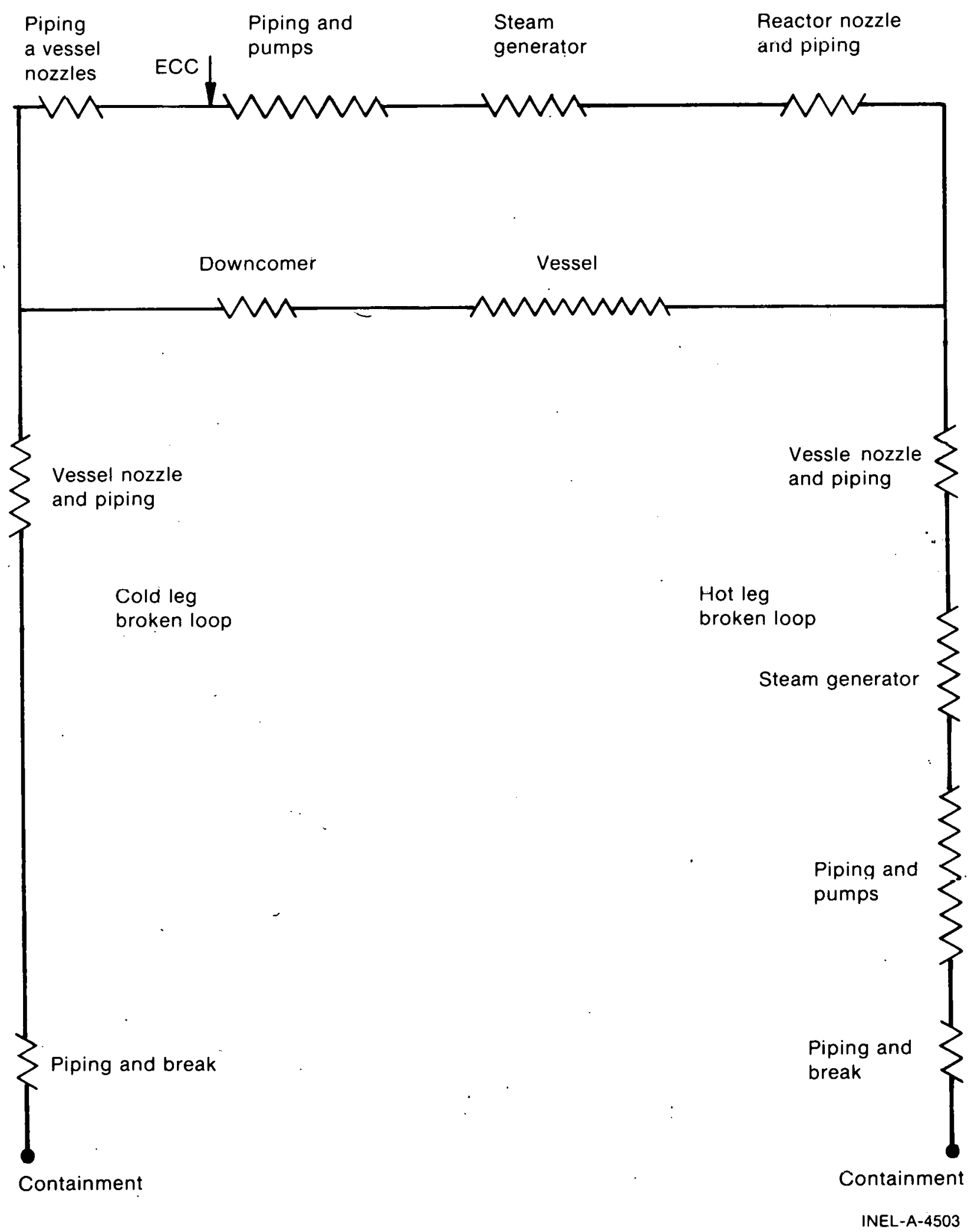

Fig. 1 Resistance network for core flooding. 
resistance must be scaled the same as the core to achieve a correct flow split during reflooding.

The above discussion has shown that for water reactor safety testing it is desirable to scale the intact loop hydraulic resistance according to volume ratio (high resistance) for blowdown simulation and to core area ratio (low resistance) for reflood simulation. In order to resolve this contradiction, experiments and accompanying analyses have been performed in several experimental facilities incorporating high and low intact loop hydraulic resistances. The following sections contain a description of the analytical models used, the analytical results and a discussion of the experimental facilities and results of the experiment conducted. 


\section{ANALYSES}

The blowdown and reflood phases of a LOCA are modeled by separate computer codes. For the LOFT facility, the blowdown phase has been modeled by a combination of RELAP4/MOD5 and FRAP-T2. The reflood phase was modeled by FLOOD4. The Semiscale MOD-1 facility was modeled during the blowdown phase by the RELAP4 computer code. The following sections describe the codes; the models used, and the results obtained.

\section{LOFT BLOWDOWN ANALYSIS}

The computer code applied to the LOFT blowdown analysis is a combination of the RELAP4/MOD5 ${ }^{[2]}$ and the FRAP- $2 T^{[3]}$ codes. A basic system model is first set up with the RELAP4/MOD5 code. The calculated conditions in the upper and lower plenums become the initial and boundary conditions for the combined RELAP-FRAP (RE-FRAP) core hot pin calculations. The combined code provides improved modeling of the fuel rod internal thermodynamics which gives a better calculation of fuel rod clad surface temperature than could be achieved with RELAP4/MOD5 alone.

\subsection{LOFT RELAP4/MOD5 System Mode 1}

The RELAP4/MODD system model (Figure 2) consists of 35 volumes and 41 junctions. The pumps are modeled as a single unit and the lower plenum is modeled as two volumes. The peak linear average power is $52.5 \mathrm{~kW} / \mathrm{m}$. ECC accumulator injection begins at 17.4 seconds; ECC lowpressure injection system (LPIS) begins at 22.2 seconds; and ECC highpressure injection system (HPIS) begins at 36 seconds. The power after SCRAM follows the American Nuclear Society (ANS) decay curve. 


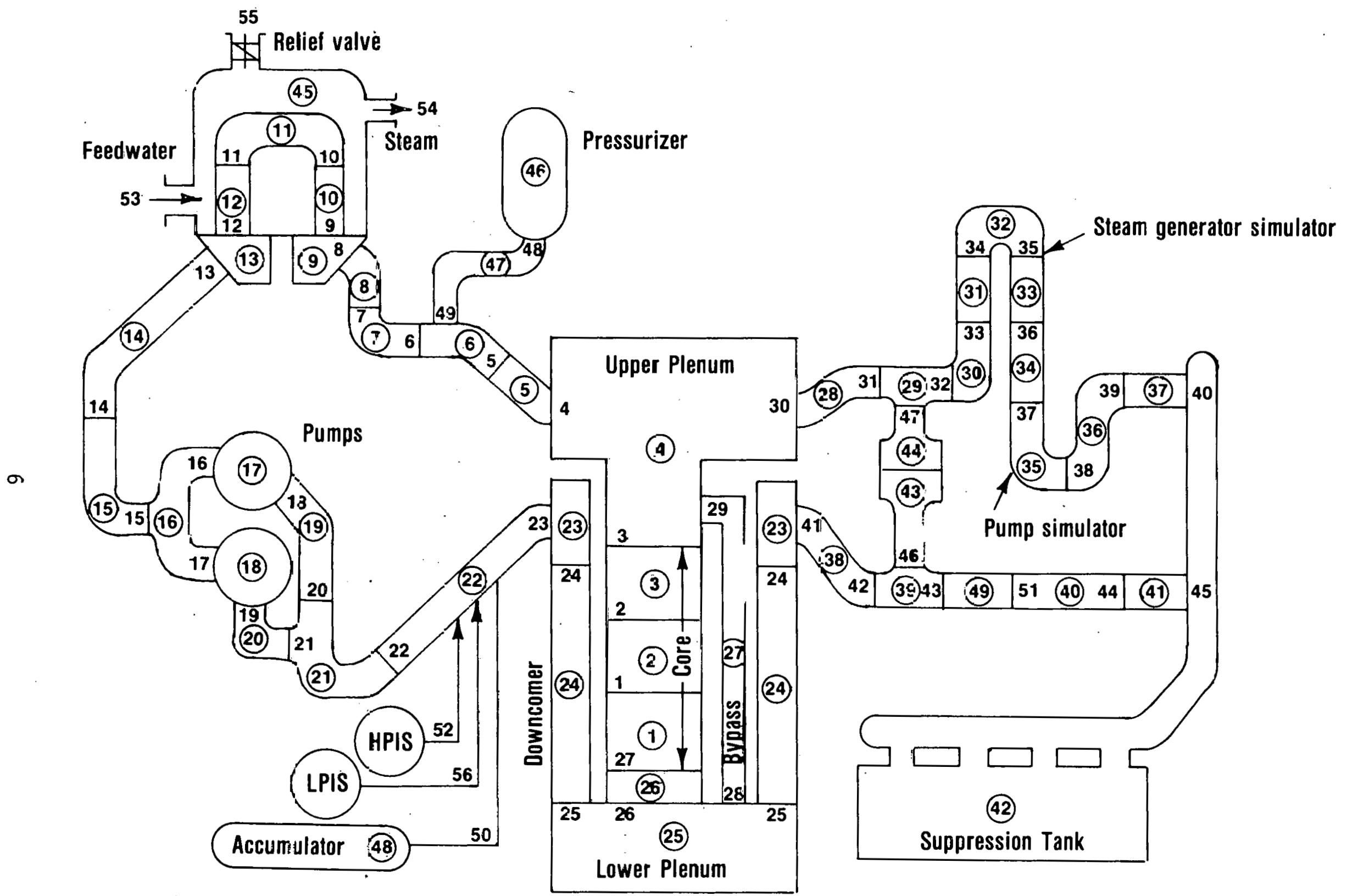

Fig. 2 LOFT RELAP nodalization. 


\subsection{LOFT RE-FRAP Model}

The RE-FRAP hot pin model (Figure 3 ) is composed of 14 volumes, 12 heat slabs, and 13 junctions. The model has no downcomer model and is for the hot pin.

\subsection{Results of LOFT Blowdown Calculations with RE-FRAP}

The RELAP (RE-FRAP) analysis is for a scaled resistance for the high hydraulic resistance case and $31 \%$ of that resistance for the low resistance case.

The comparisons of the results of these two calculations are presented as time histories between 0 and 22 seconds. The parameters which are expected to show the effects of intact loop resistance variation are the cold and hot leg densities and flow. rates, the pump coastdown, the downcomer flow rate and density, the core fluid and clad temperatures, and the core flow rate.

The intact loop cold leg density and weight flow, Figures 4 and 5, show essentially no dependence on flow resistance. The intact loop hot leg density, Figure 6, has a higher density for low resistance early in transient (from 5 to 7 seconds) switching to lower density for low resistance in the middle of the transient ( 9 to 13 seconds) and no effects due to resistance from 13 seconds on. The change in density response is caused by an earlier and longer flow reversal, Figure 7, at 5 seconds for the low resistance case. It is apparent that the change in steam generator resistance has had a slight effect on the flow back to the vessel, but not through the pump. 

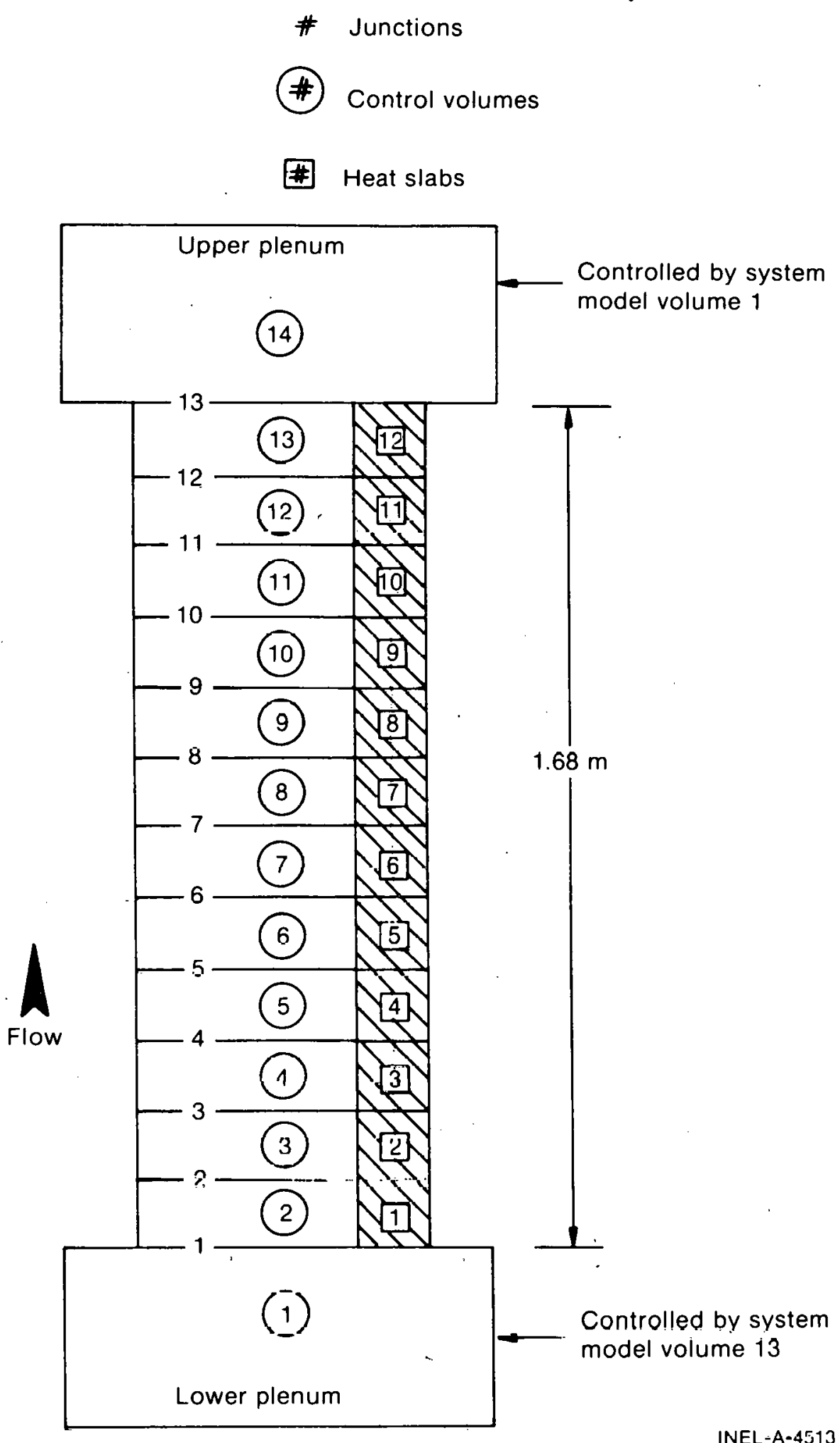

Fig. 3 Schematic of hot pin model. 


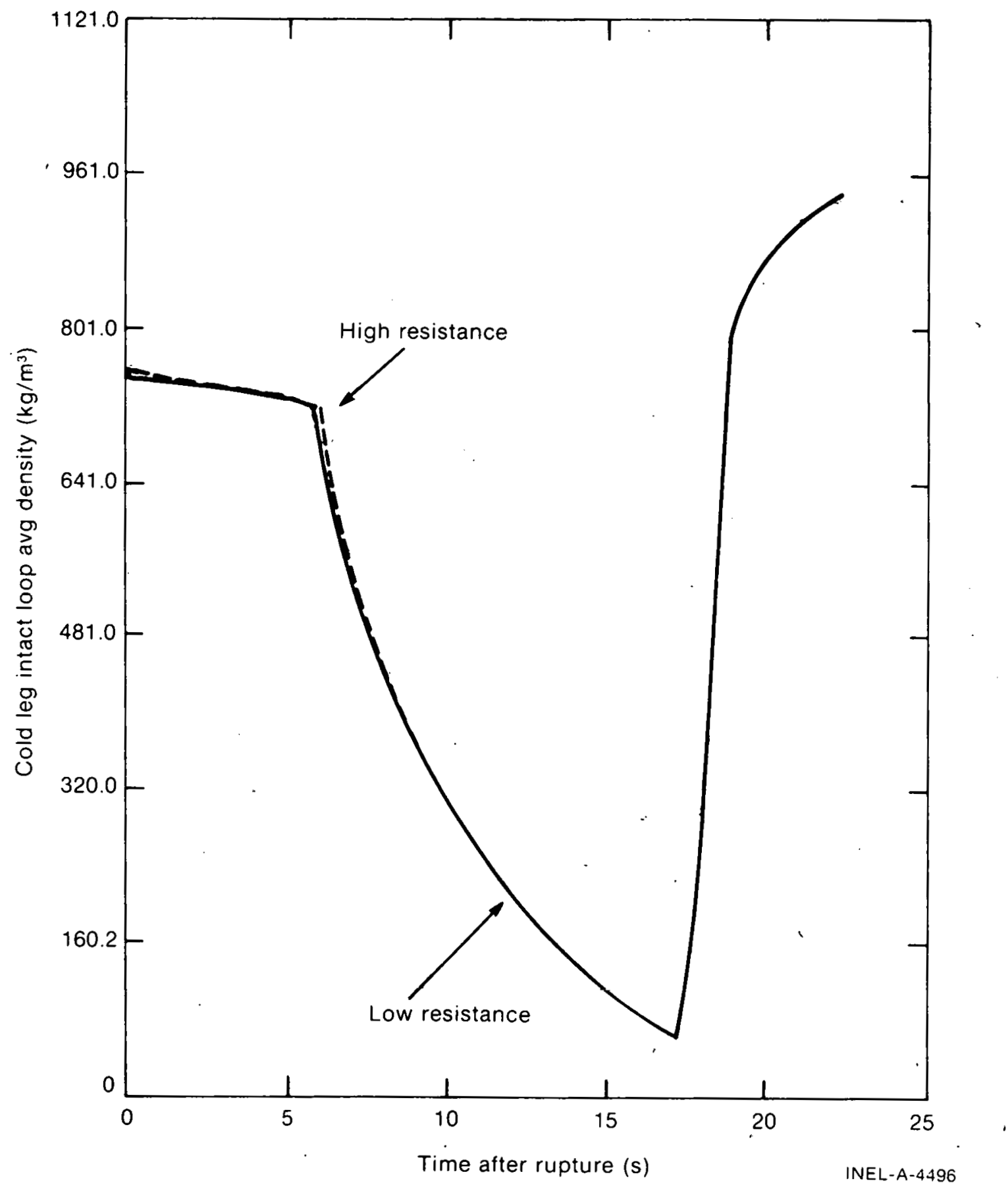

Fig. 4 Density response -- average core RELAP model. 


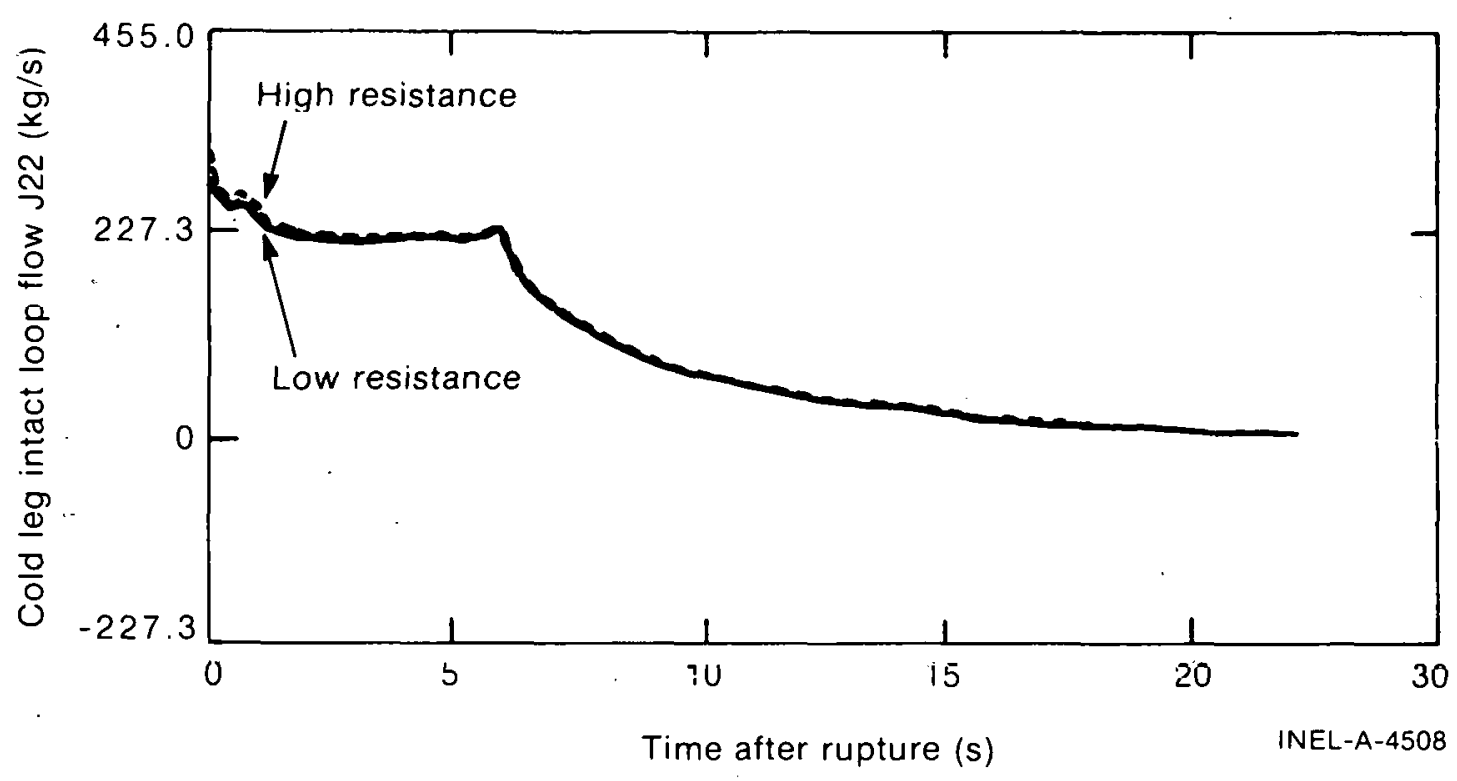

Fig. 5 Cold leg intact loop response -- average core LOFT RELAP model.

The flow in the downcomer, figure 8 , reverses immediately upon the initiation of blowdown. The flow increases to a maximum positive flow at 5.6 seconds and then drops to a negative flow for the duration of the blowdown. Intact loop resistance has no effect on downcomer flow.

The downcomer density histories, figure 9, show similar behavior for both resistances. The low resistance downcomer density remains high for $3 / 4$ second at approximately the time of maximum positive flow (6-3/4 seconds). The source of this higher density fluid is the core which has lower quality for the low resistance case at 5 to 6 seconds, as shown in Figure 10, due to a slightly later core flow reversal for the low resistance case, Figure 11. Another effect of the high core quality for high intact loop resistance is the 6.7 to $15.6^{\circ} \mathrm{C}$ higher hot spot clad temperature, Figure 12 . The difference in quality and reversal can be attributed to the slight differences in the calculated flow, Figure 11. 


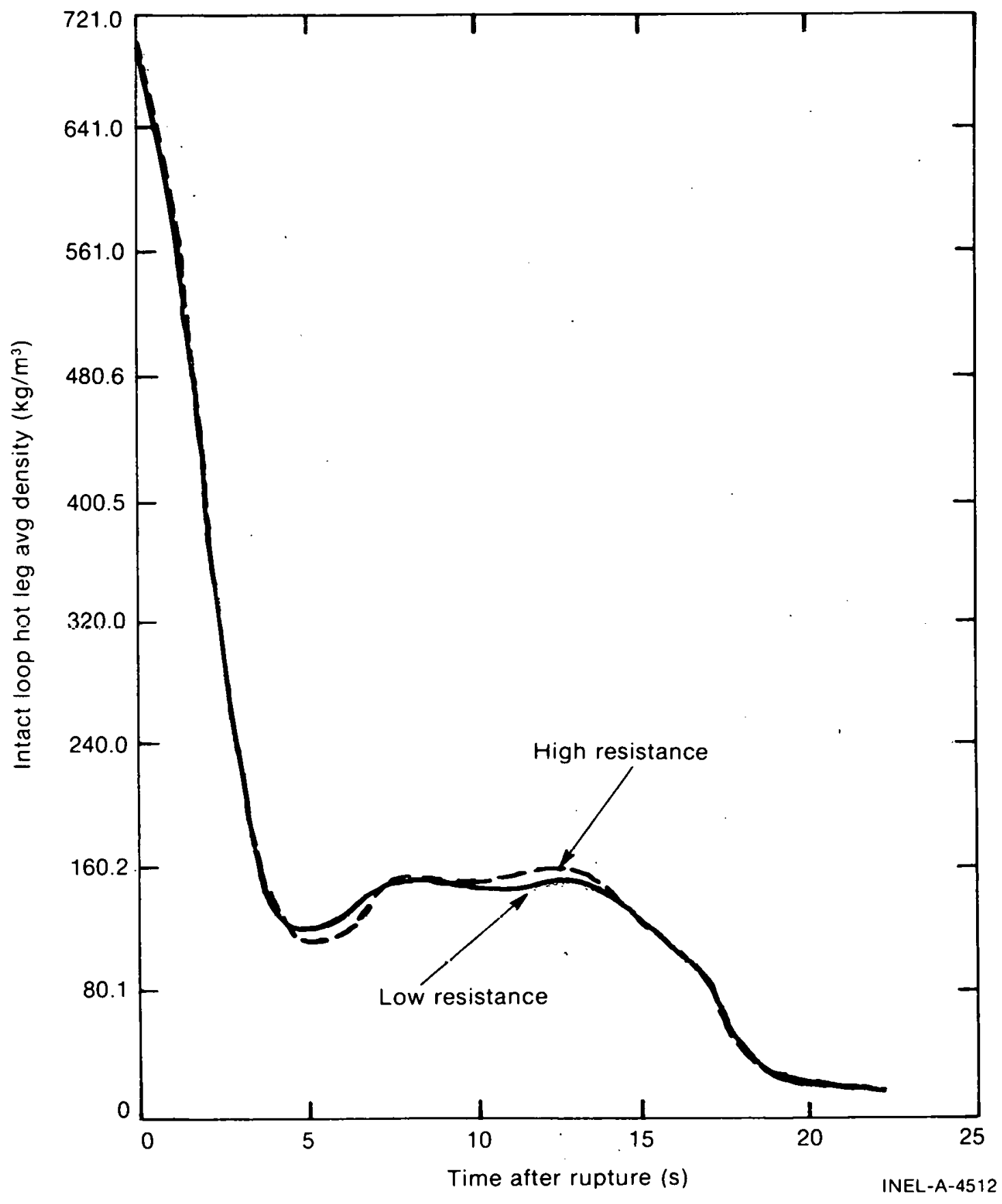

Fig. 6 Density response average core -- LOFT RELAP model. 


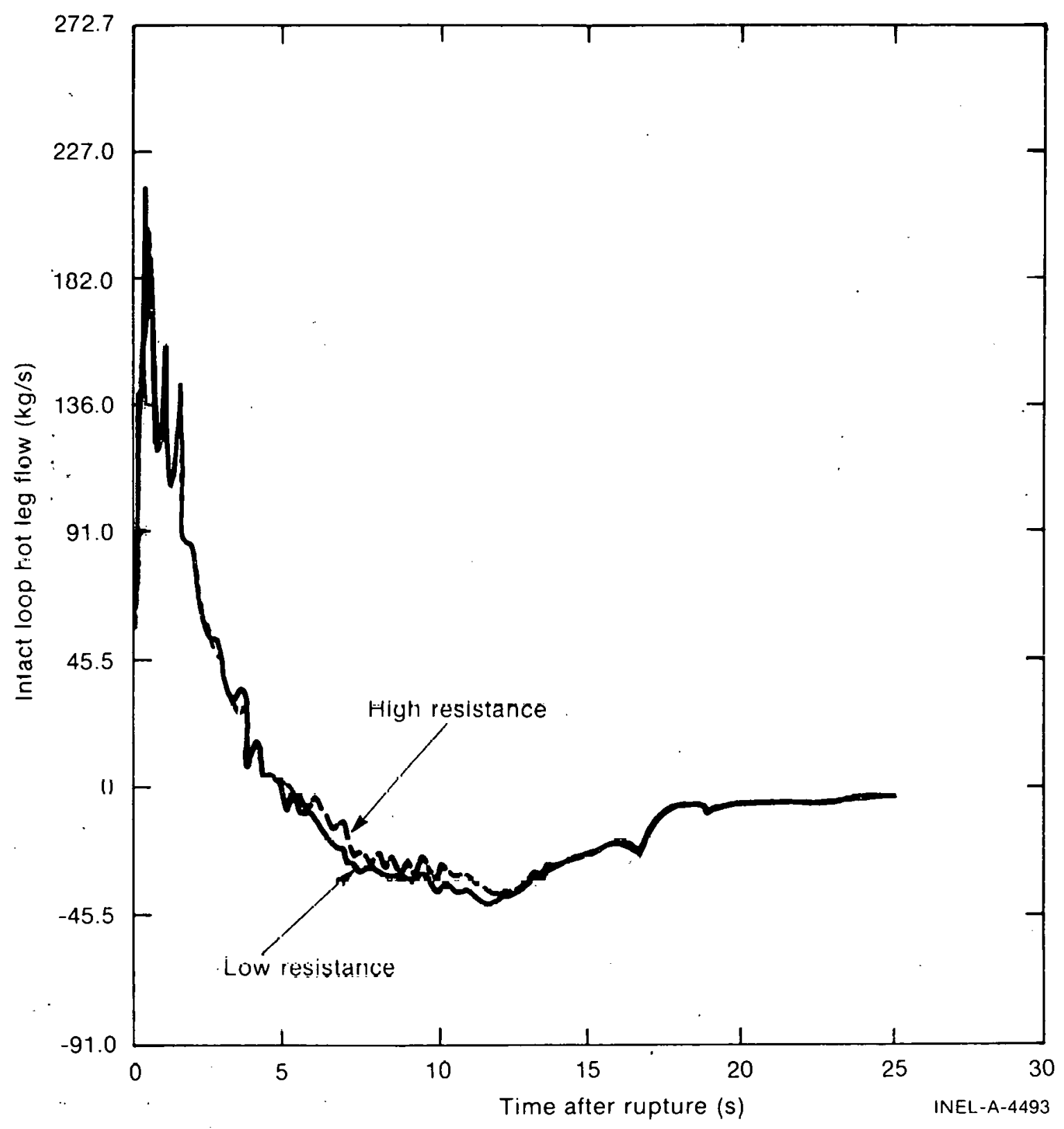

Fig. 7. Hot leg intact loop. flow response -- average core LOFT RELAP model. 


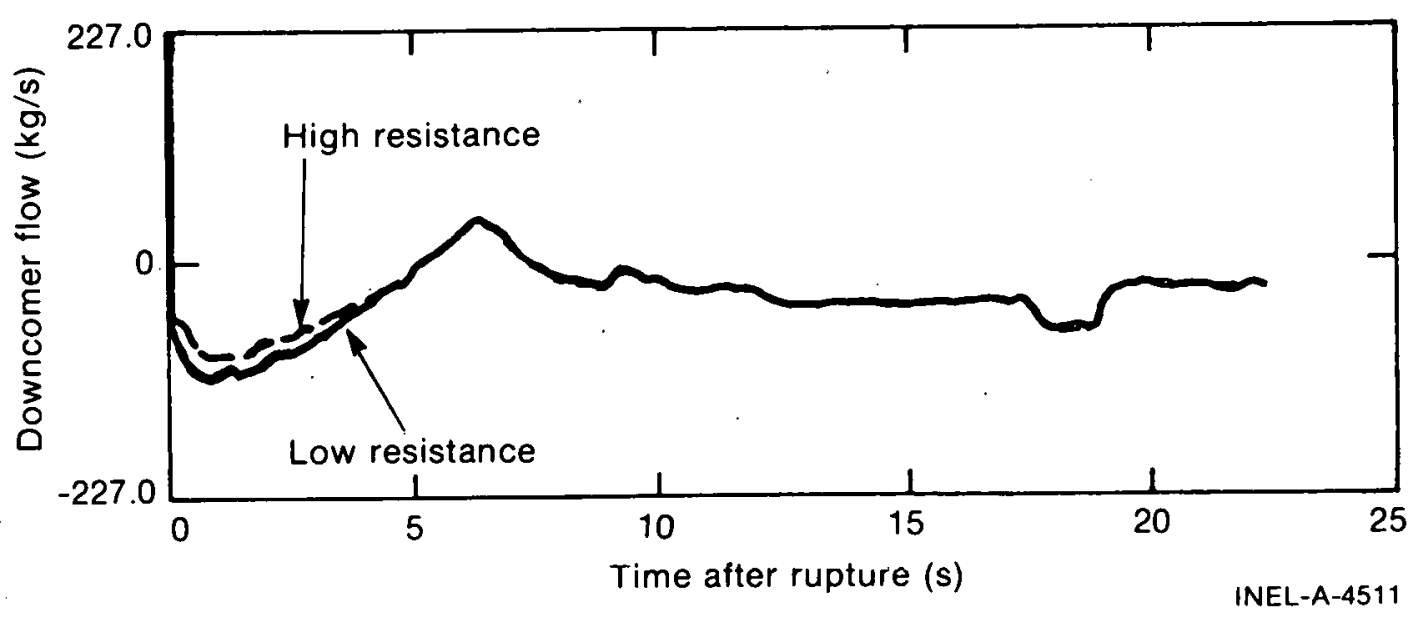

Fig. 8 Downcomer flow response -- average core LOFT RELAP model.

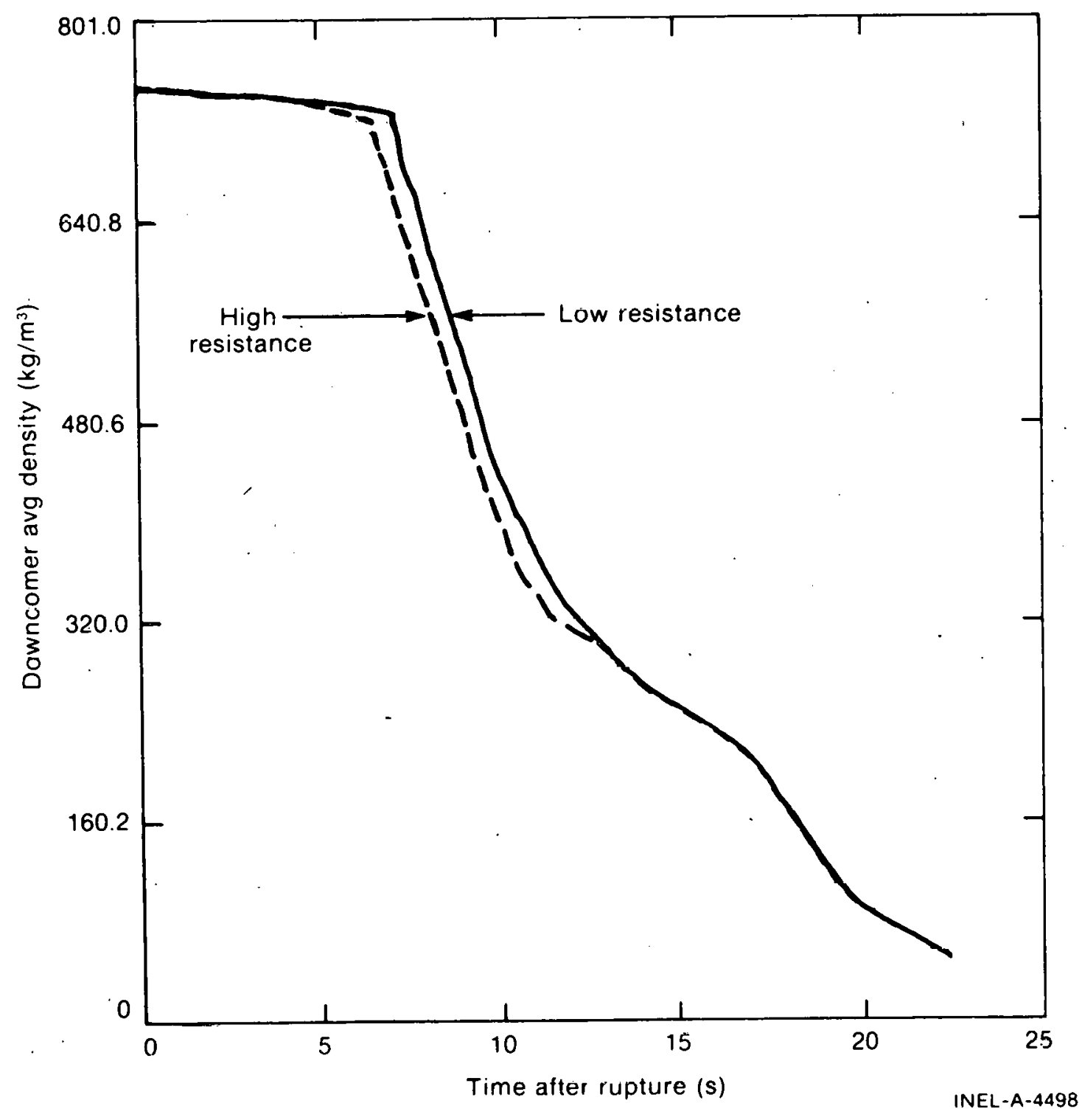

Fig. 9 Downcomer density response -- average core LOFT RELAP model. 


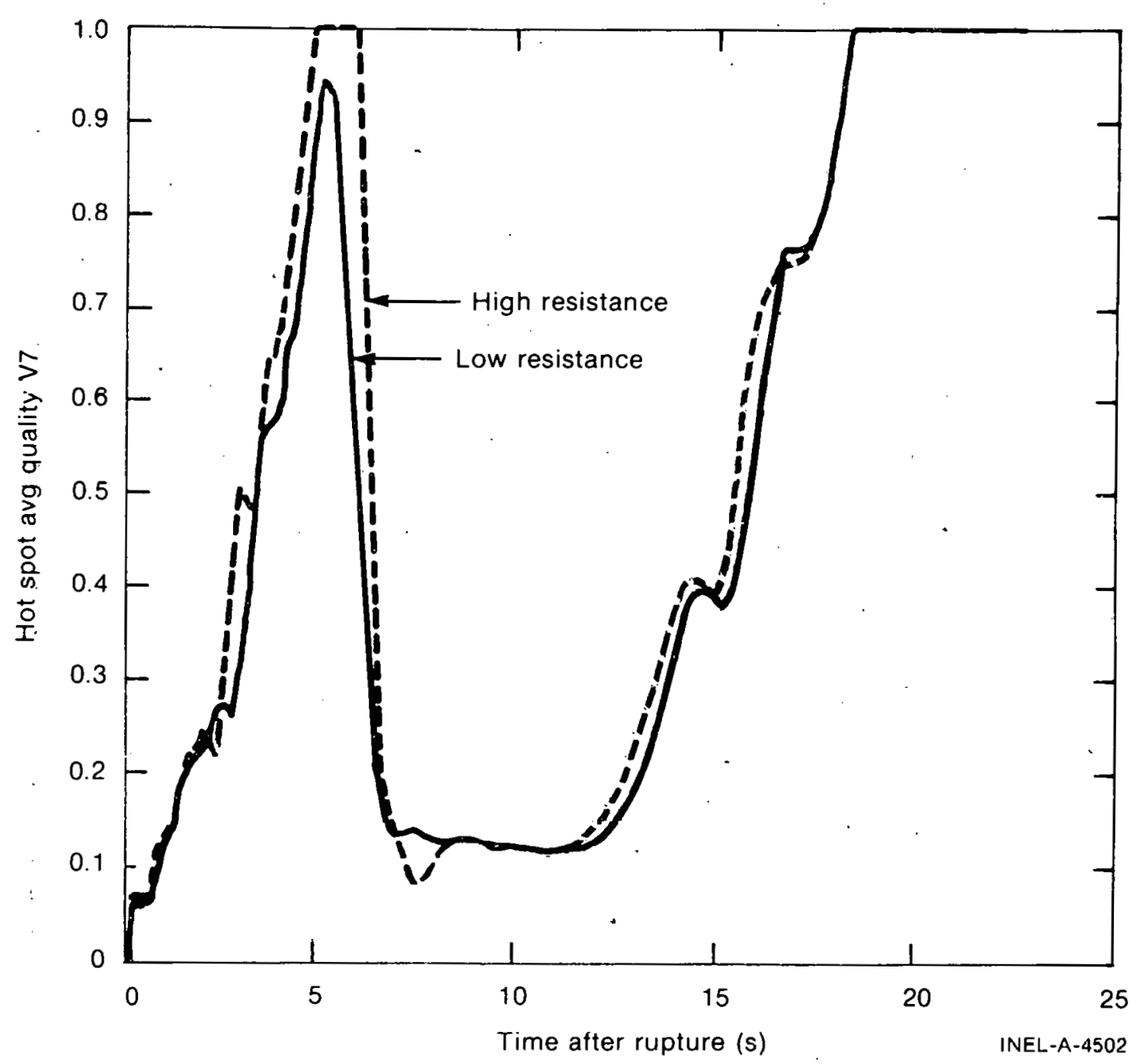

Fig. 10 Average hot spot quality -- hot pin IOFT RF-FRAP model.

\section{LOFT REFLOOD ANALYSIS}

The LOFT reflood regime is modeled with the FLOOD4 computer code. The FLOOD4 code ${ }^{[4]}$ solves a momentum equation for the fluid in the core, lower plenum, and annulus. The momentum equation includes the rate of change of momentum of the water mass, the friction and geometry change pressure losses, the water elevation difference between the core and 
annulus, and the pressure difference between the core and the upper annulus.

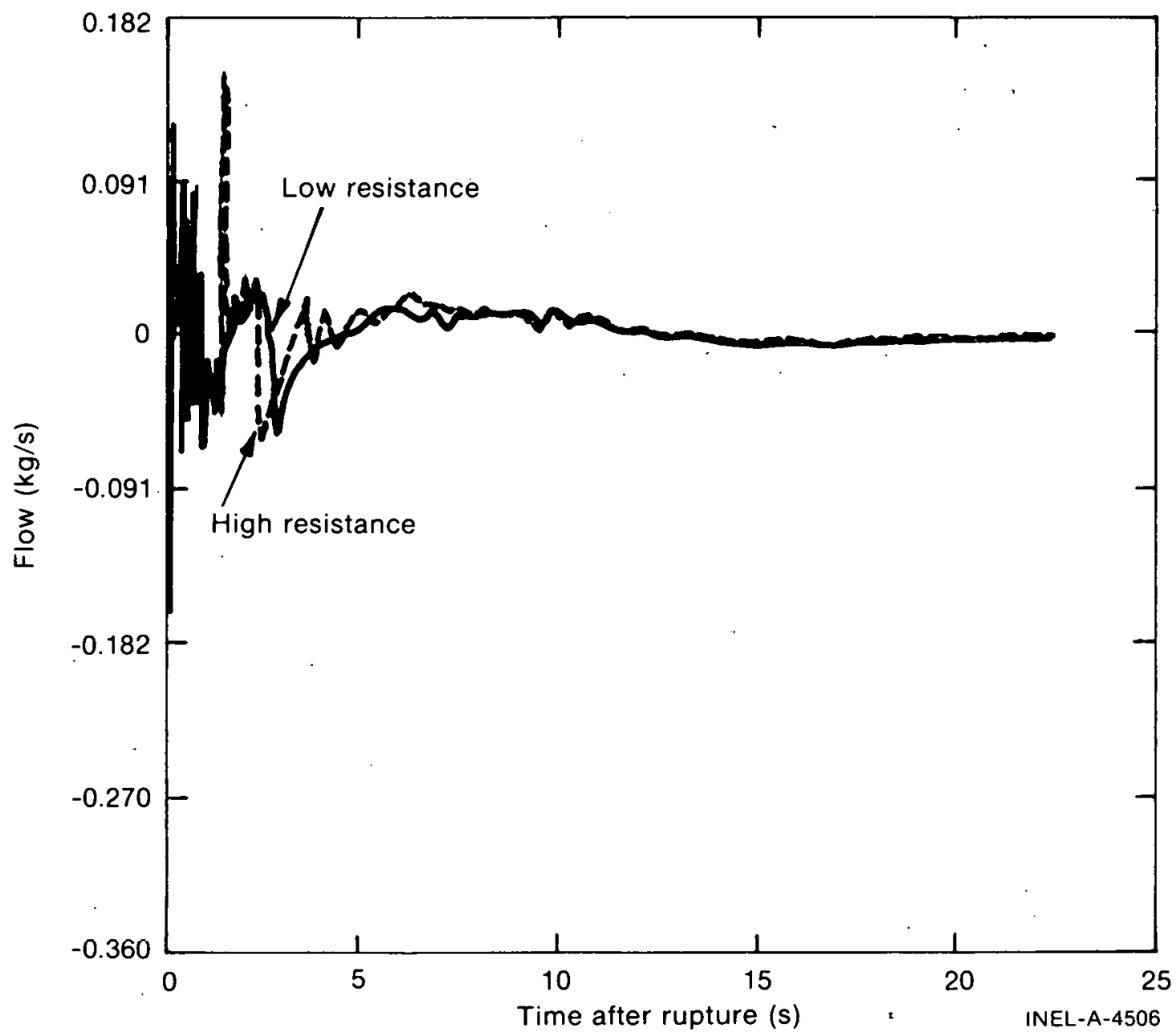

Fig. 11 Lower plenum flow response -- hot pin LOFT RE-FRAP model.

The steam within the system is represented by one gas volume because the majority of the loop volume is upstream of the large resistance (the pump). The perfect gas law is used to define the relationship among the steam pressure, mass, volume, and temperature.

Liquid which rises in the annulus to a height greater than that of the cold leg is assumed to be lost from the system. 
The core thermal energy is contained in axially stacked conduction nodes. Heat transfer coefficient (HTC) approximations to the boiling curve are applied to the nodes depending on the node elevation, the water elevation, and the node temperature. The amount of steam leaving the core is a function of the heat flux from nodes above the quench front, and the amount of liquid entrained in the steam is a function of steam flow rate, water level, pressure, and core hydraulic diameter.

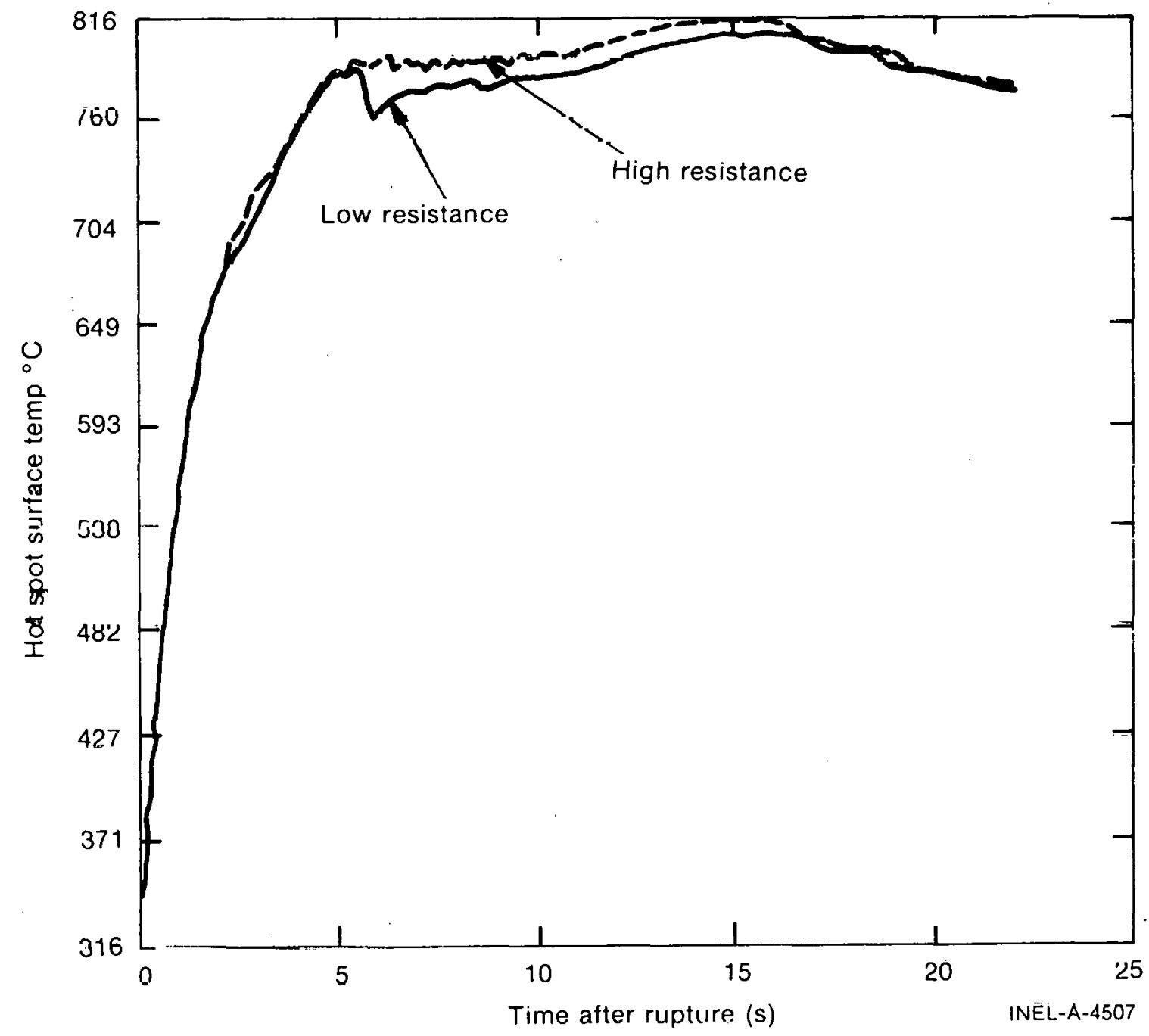

Fig. 12 Clad temperature response -- hot pin LOFT RE-FRAP model.

The FLOOD4 calculations are performed with the thermodynam1c boundary conditions provided by RELAP4/MOD5 and fuel conditions from FRAP at the time of end of refill. 


\subsection{LOFT FLOOD4 MODEL}

A sketch of the FLOOD4 model and nodalization is shown in Figures 13 and 14. The $1.68-\mathrm{m}$ rod is divided into 120 axial volumes and 9 radial volumes with a node point at the center of each volume and one node at the outside surface. Initial conditions are obtained from the RELAP average core run at the time of start of REFLOOD (38.6 seconds after initiation of blowdown at $100 \%$ power).

\subsection{LOFT FLOOD4 RESULTS}

The results of the FLOOD4 calculations for normal and twice normal intact loop resistances are presented as the time histories for the clad hot spot temperature, Figure 15. The low intact loop resistance case has a higher hot spot temperature. The difference reaches a maximum of $26.7^{\circ} \mathrm{C}$ at the time the quench front reaches the hot spot. Since the clad temperature is constantly decreasing, this temperature difference is of no importance. A similar result was reached for the FLOOD4 analysis of Semiscale $e^{[4]}$. 


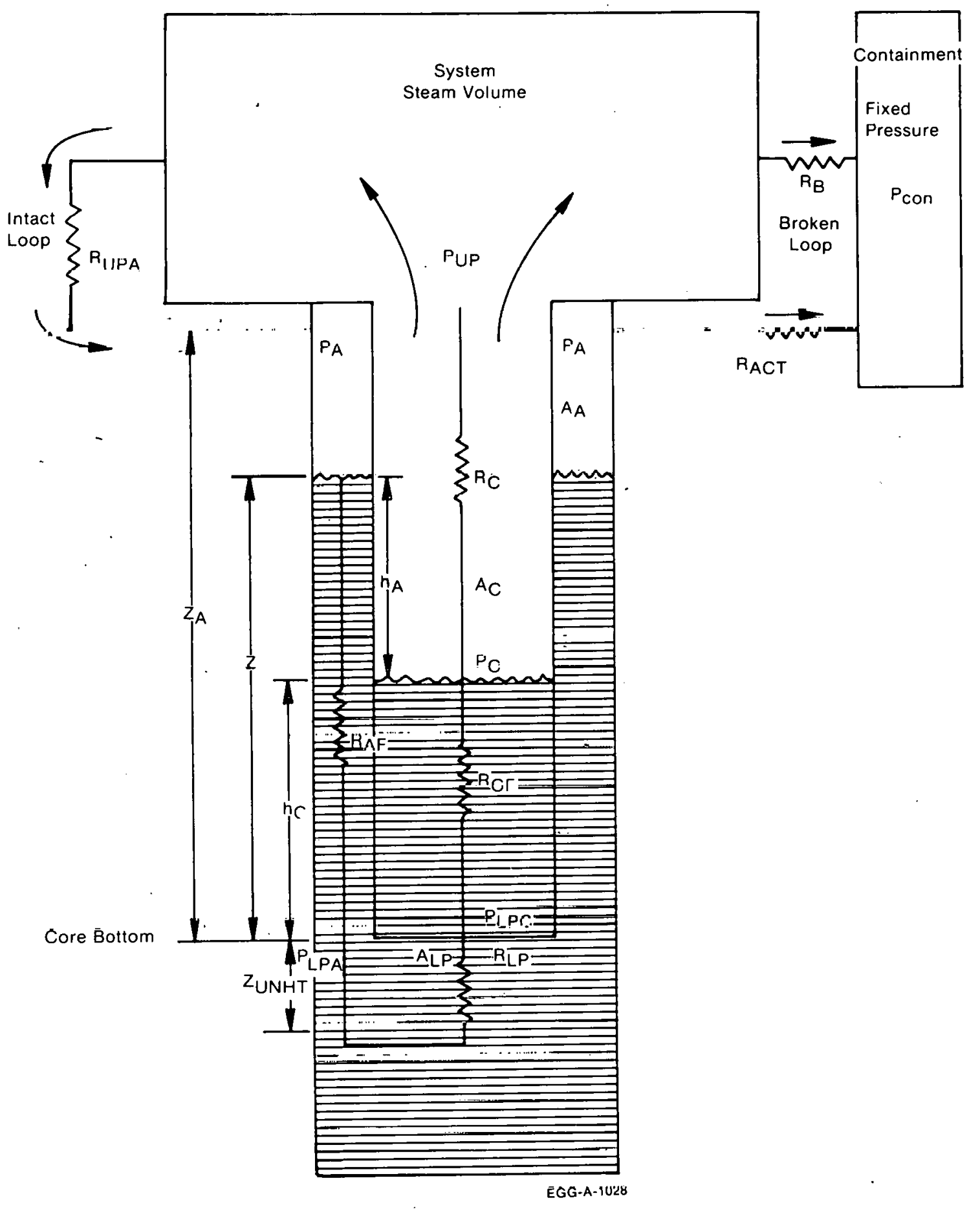

Fig. 13 sketch of FLOOD-4 model. 

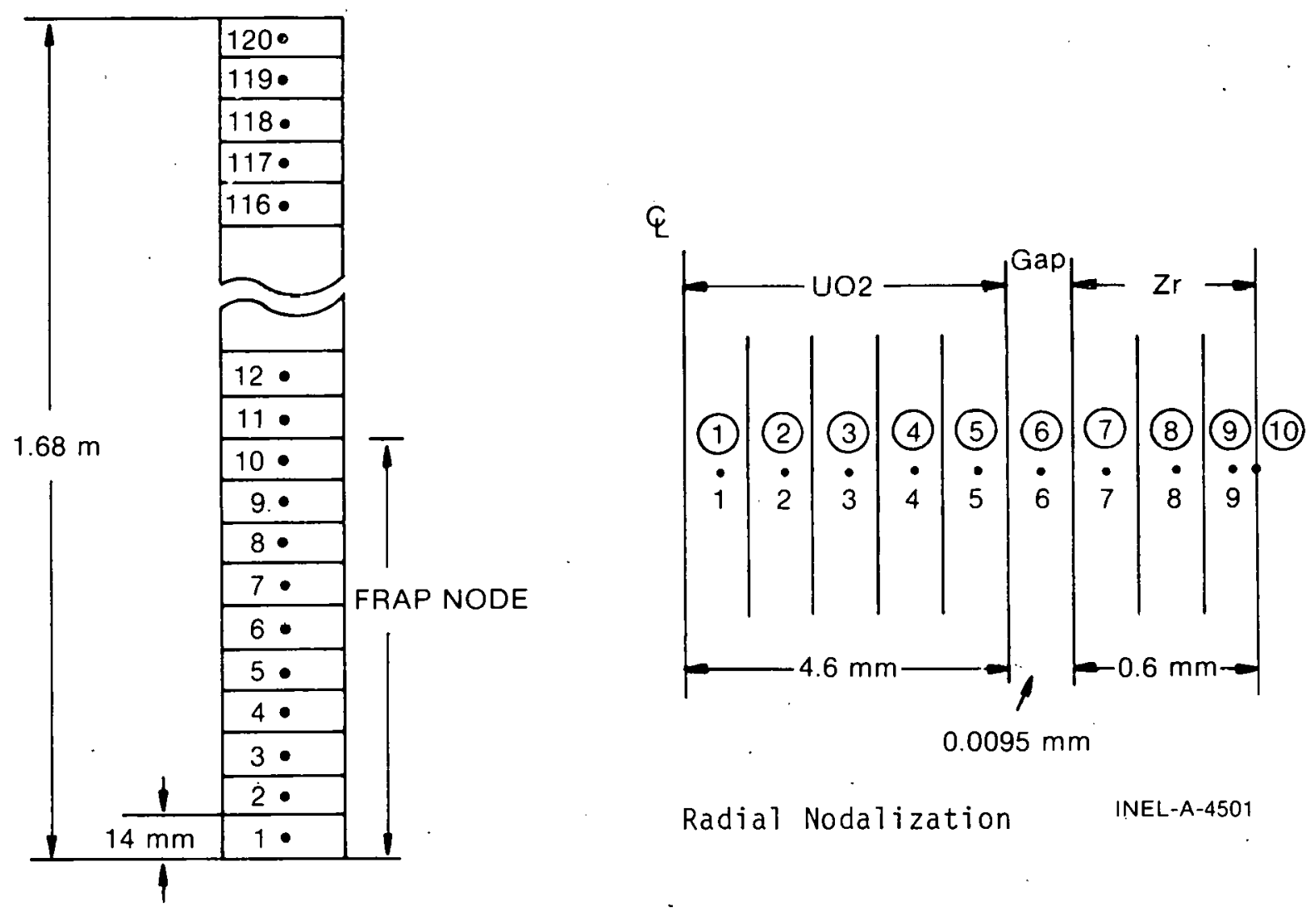

Radial Nodalization

INEL-A-4501

Axial Nodalization

Fig. 14 Fuel rod nodalization for LOFT FLOOD-4 model. 


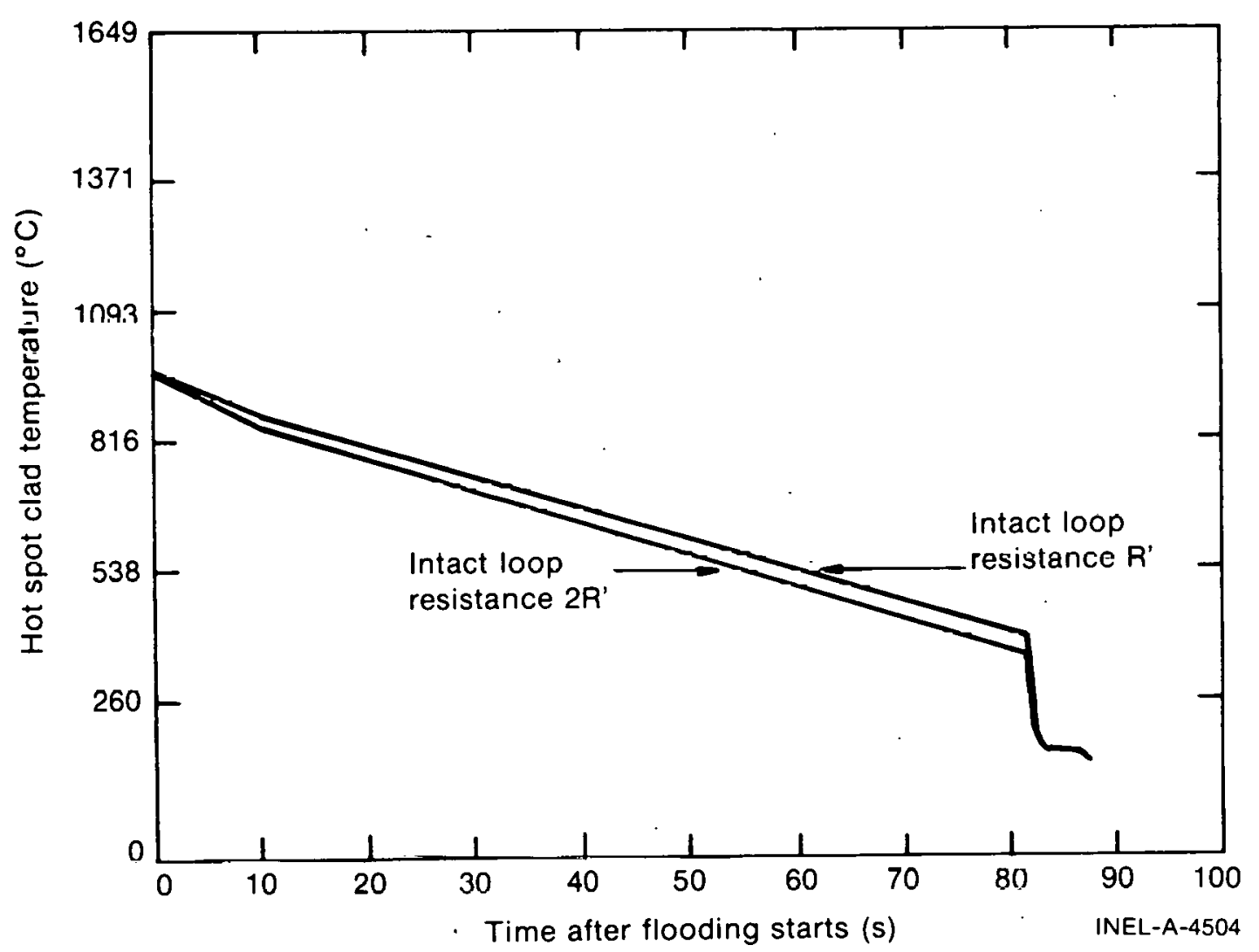

Fig. 15 Clad temperature response -- LOFT FLOOD-4 model. 


\section{EXPERIMENTS}

The LOFT, Semiscale MOD-1 and FLECHT-SET facilities have been utilized for tests where a single parameter, intact loop flow resistance, has been varied. Data from LOFT isothermal blowdowns, Semiscale, REFLOOD, and FLECHT-SET reflood tests have been considered for this study.

\section{LOFT ISOTHERMAL BLOWDOWN TESTS SYSTEM CONFIGURATION}

The LOFT system is designed to simulate the major components of a LPWR during a LOCA. The system consists of five parts: the reactor vessel, the intact loop, the broken loop, the suppression system, and the ECCS. Design details of these systems are described in Reference 4.

The reactor vessel simulates the reactor vessel of a LPWR. It has an annular downcomer which connects with the cold leg of both the intact and the broken loops, a lower plenum, lower core support plates, a core simulator which contains orifices which simulate the resistance of the nuclear core, and a upper plenum which connects with the hot leg of both the intact loop and the blowdown system.

The LOFT intact loop simulates the three unbroken loops of a fourloop LPWR. This loop contains a steam generator, two pumps (connected in paral1e1), a pressurizer, a venturi flowmeter, and connecting piping.

The primary side of the steam generator contains two square-edged orifices in the inlet and outlet plenums that are sized for either high resistance (volume scaling) or low resistance (core area scaling).

The LOFT broken loop simulates the broken loop of a LPWR. It consists basically of two lines that are connected between the reactor vessel and the suppression tank header.. Each line consists of a break 
plane orifice which determines the break size to be simulated, a quickopening blowdown valve (QOBV) which simulates a pipe break, an isolation valve, and connecting piping.

The experiments considered are for a $200 \%$ cold leg break. This is a simulation of a double-ended pipe shear in the cold leg of one of the loops in a LPWR. In this configuration, the hot leg line of the blowdown system contains, in addition to the above mentioned equipment, steam generator and pump simulators.

The ECCS consists of a LPIS, a HPIS, and an accumulator system. The LPIS is used principally to satisfy the core cooling requirements following large primary system, breaks. The principal use of the HPIS is to prevent damage to the core for small area breaks and to aid in intermediate breaks. The accumulator system is designed to supply the LOFT core with ECC in the event of large or intermediate piping breaks. The accumulator system consists of two accumulator tanks, which are pressurized with nitrogen gas, the associated valves, and piping necessary to dcliver accumulator fluid to the cold leg injection point.. One accumulator (A) was used and the other was maintained in a standby condition. The LOFT major components are shown pictorially in Figure 16, Reference 5 a detailed description of the LOFT system, and References 6 and 7 give details of the experiment configuration and operation.

\section{LOFT EXPERIMENTAL RESULTS}

LOFT tests $L i-2,-3$, and $-3 A$ were performed for the purpose of comparing the effects of intact loop resistance. LI-2 had $90 \%$ more intact loop resistance (including vessel resistance) than $L 1-3$ or $-3 A$. $L 1-2$ had no ECCS flow until late in the blowdown and L1-3 had oniy HPIS and LPIS. LI-3A had ECC injection at the normal times. The data for these experiments have been reported by Robinson [8], Chappe11 [9], and Millar [10]. The results of these experiments are presented as time 


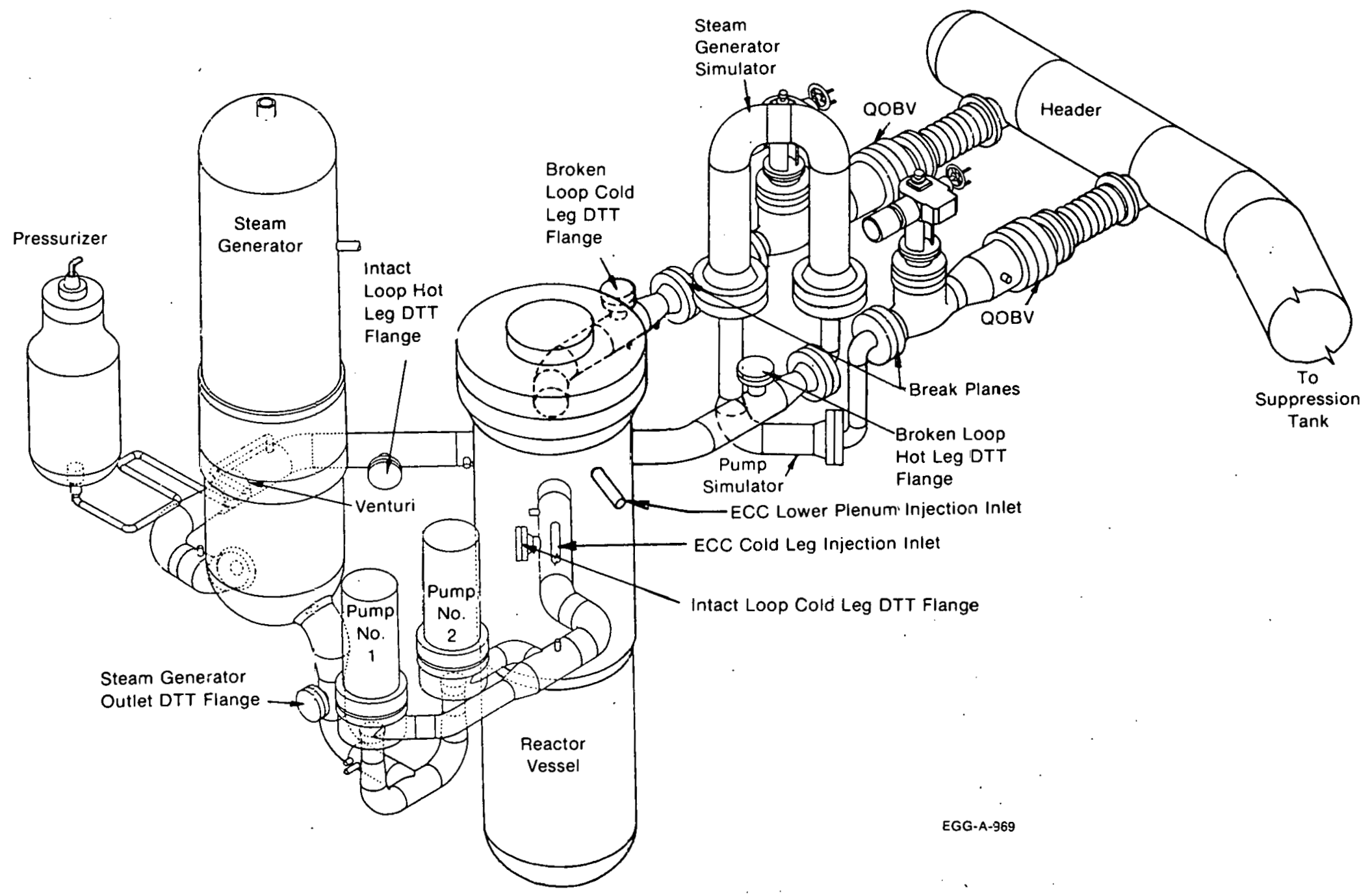

Fig. 16 Major LOFT components. 
histories. All available parameters have been examined. The pressure in the core simulator (Figure 17) shows a rapid depressurization at time zero from 15.17 to $5.5 \mathrm{MPa}$ with a gradual pressure drop until approximately 22.5 seconds when accumulator injection began in Test L1-3A. The maximum difference during the blowdown period is less than $69 \mathrm{kPa}$. In the experiments without ECC accumulator injection, the time histories are identical. The fluid temperature/time history, figure 18, has the same trends. The effect of ECC injection at 22.5 seconds is shown by the faster temperature drop in $L 7-3 A$ at 27 seconds. The differences in temperature are within the accuracy of the instrumentation. 0ther parameters, cold and hot leg densities, and flows, which were examined, also showed no difference due to resistance. 


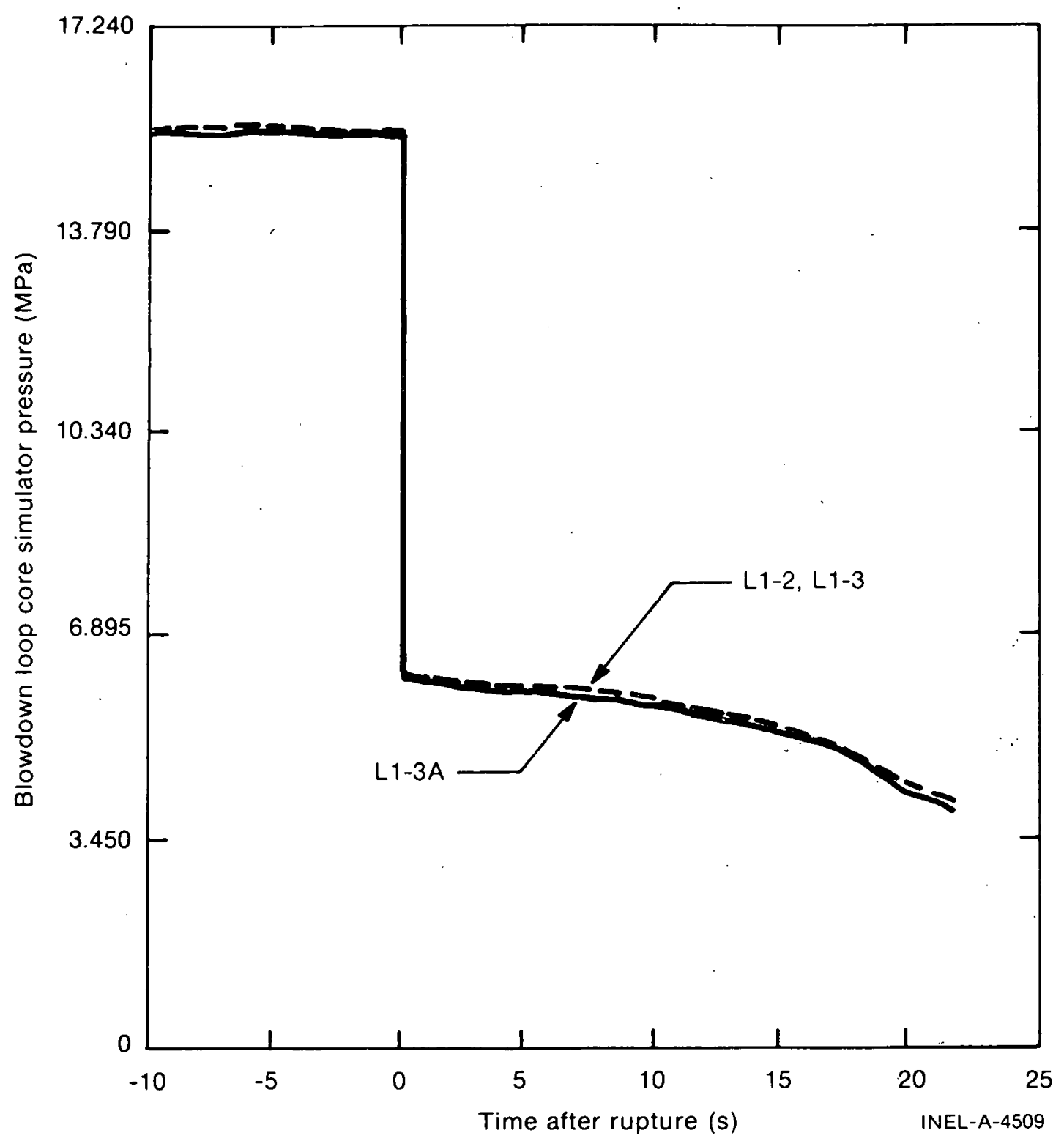

Fig. 17 LOCE pressure response -- LOFT isothermal blowdown. 


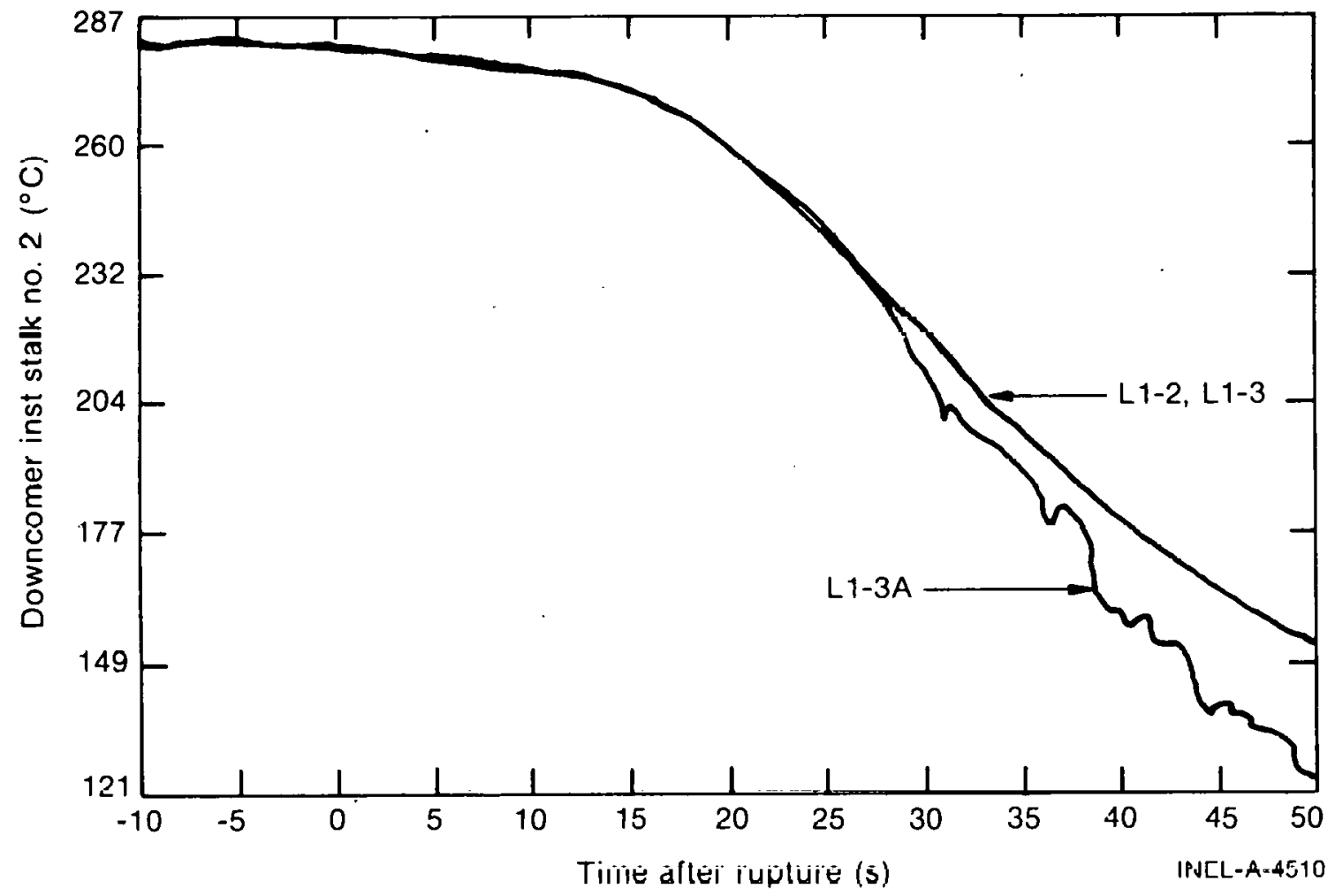

Fig. 18 Downcomer fluid temperature -- LOFT isothermal blowdown. 


\section{SEMISCALE ISOTHERMAL BLOWDOWN AND REFLOOD TESTS}

This section contains a description of the Semiscale MOD-1 test system and a description and results of the isothermal blowdown and refill testing.

The Semiscale Mod-1 experimental program conducted by EG\&G Idaho, Inc., is part of the overall U. S. Nuclear Regulatory Commission and Energy Research and Development Administration sponsored research and development program to investigate the behavior of a pressurized water reactor (PWR) system during a hypothesized LOCA. The Semiscale MOD-I program is intended to provide transient thermal-hydraulic data from a simulated LOCA using a small-scale experimental nonnuclear system.

The Semiscale MOD- 1 tests are performed with an experimental system which simulates the principal physical features of a ruclear plant but which is much smaller in volume. Nuclear heating is simulated in the tests by a core composed on an array of 40 electrically heated rods.

The Semiscale MOD-1 system configuration consists of a pressure vessel with simulated reactor internals; an intact loop with steam generator and an active pump; a broken loop arranged in the cold leg break configuration with a simulated steam generator, simulated pump, and pipe rupture assemblies; a pressure suppression system with header, suppression tank, and steam supply system to control the system pressure; and an ECC injection system comprising an accumulator and injection pump. A detailed description of the system configuration including the system components, peripheral equipment, instrumentation, and data acquisition systems can be found in Reference 11. 


\section{SEMISCALE MOD-1 ISOTHERMAL BLOWDOWN TEST DESCRIPTION}

Tests S-01-2 and $-3^{[12],[13]}$ were conducted as part of a series of tests (Test Group 1) to provide data for comparison of the isothermal blowdown response of the Semiscale system with that of the LOFT system. The Semiscale Mod- 1 experimental configuration for this test utilized hardware components selected to produce a system performance which simulates LOFT system performance during the LOFT nonnuclear tests. Test S-01-3 employed an intact loop flow resistance that was low relative to that of Test S-01-2 to establish lle impurtance of intact loop resistance on system response during blowdown. Test S-01-3 resistance was scaled from that of the LOFT system.

Power to the primary coolant circulating pump was cut off at blowdown to allow the pump to coast down to a speed of $1300 \mathrm{rpm}$. A flywheel mounted on the pump motor shaft provided a simulation of the predicted coastdown of the LOFT pumps.

Coolant was injected into the lower plenum of the pressure vessel during blowdown. Injection from the accumulator began about 22 seconds after initiation of blowdown and continued for about 48 seconds.

Test 5-01-2 was conducted in two phases: a blowdown phase and a hot-wall phase. The blowdown phase was conducted without coolant injection to provide baseline system hydraulic behavior. Thus data after 22 seconds are not relevant to this paper.

\section{ISOTHERMAL TEST RESULTS}

The results of the isothermal blowdown Tests $5-01-2$ and -3 are reported in References 12 and 13. They are presented here as time histories of upper plenum pressure, intact loop density, intact loop mass flow, core mass flow, and lower plenum fluid temperature. 
The history of upper plenum pressure, Figure 19, shows an initial difference of $345 \mathrm{KPa}$ due to a difference in experimental initial conditions. Both low and high resistance experiments depressurized in a similar manner, never differing by greater than $345 \mathrm{KPa}$.

The history of the intact loop cold density, Figure 20 , shows that the high resistance density begins to drop 2 seconds early at 9 seconds. After 14 seconds, the density histories are identical. The difference in the densities occurs at the time of minimum intact loop flow, Figure 21. There is no difference in flow which can explain the density histories. However, there is a $2.8^{\circ} \mathrm{C}$ difference in fluid temperature at 10 seconds which, combined with the $345 \mathrm{KPa}$ initial pressure difference, may cause the steam production to be higher earlier for the high resistance case.

The core flow history, Figure 22, shows no great differences caused by system resistance.

In summary, the results of isothermal testing in Semiscale show no influence in blowdown due to the $117 \%$ variation in intact loop flow. resistance.

\section{SEMISCALE MOD-1 REFLOOD TEST DESCRIPTION.}

The Semiscale reflood test configuration ${ }^{[14]}$ replaced the core simulator with an electrically heated 40 rod simulated core bundle. The cross section of which is shown in Figure 23. The bundle power was controlled to simulate the decay heating process, using the American Nuclear Society standard curve, during the reflood portion of a LOCA. 


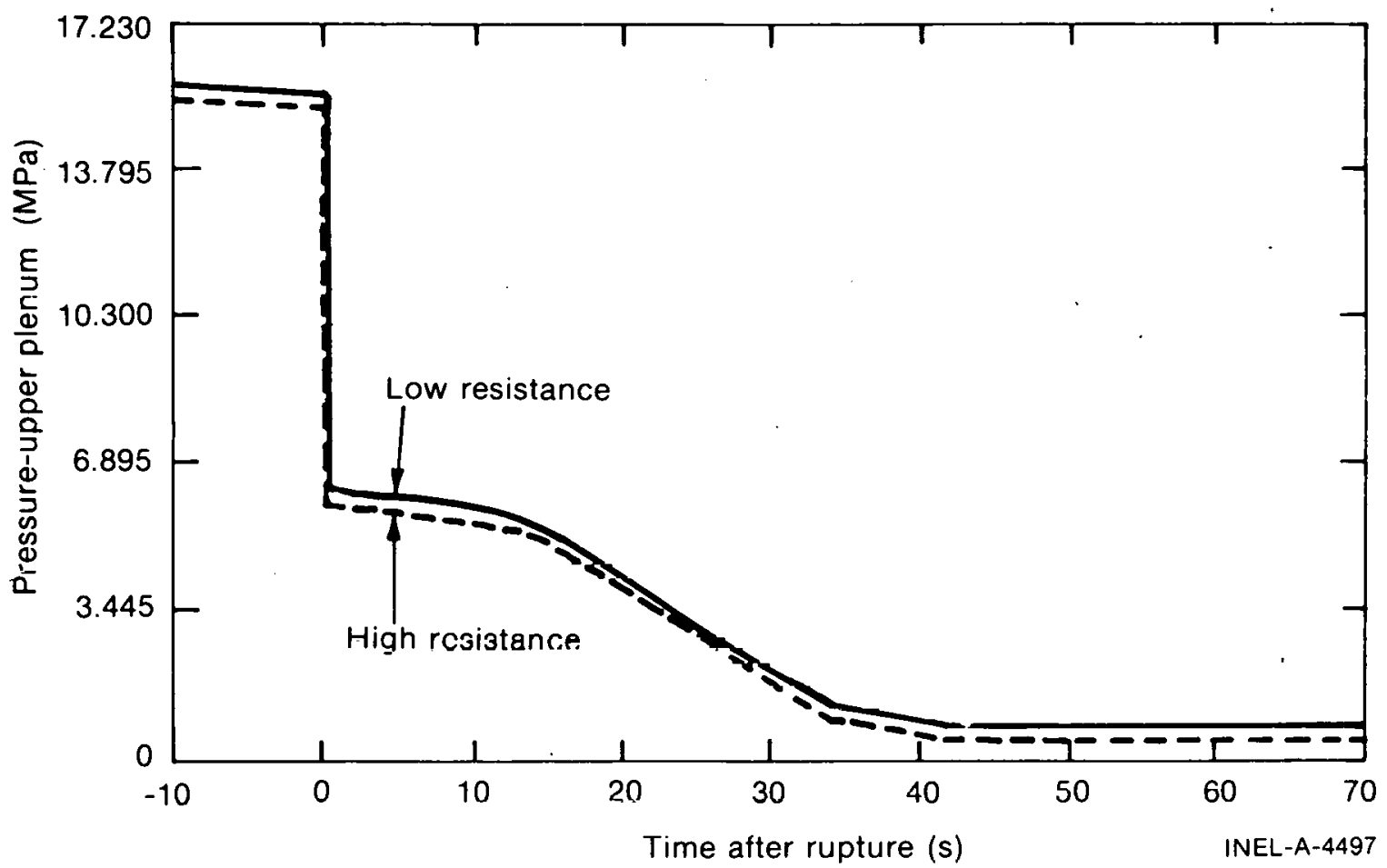

Fig. 19 Upper plenum pressure response -- Serniscale isothermal blowdown.

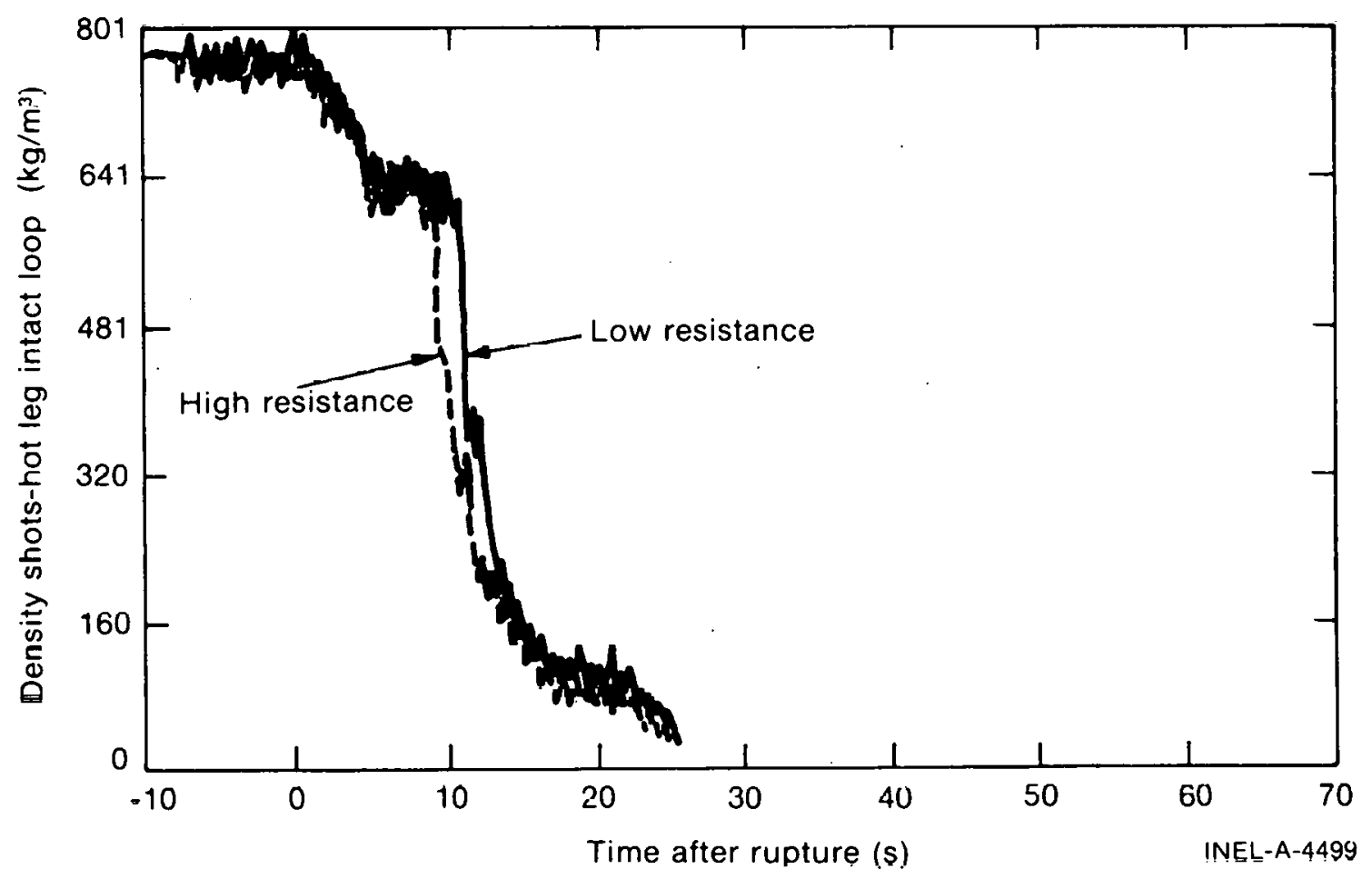

Fig. 20 Intact loop hot leg density response -- Semiscale isothermal test. 


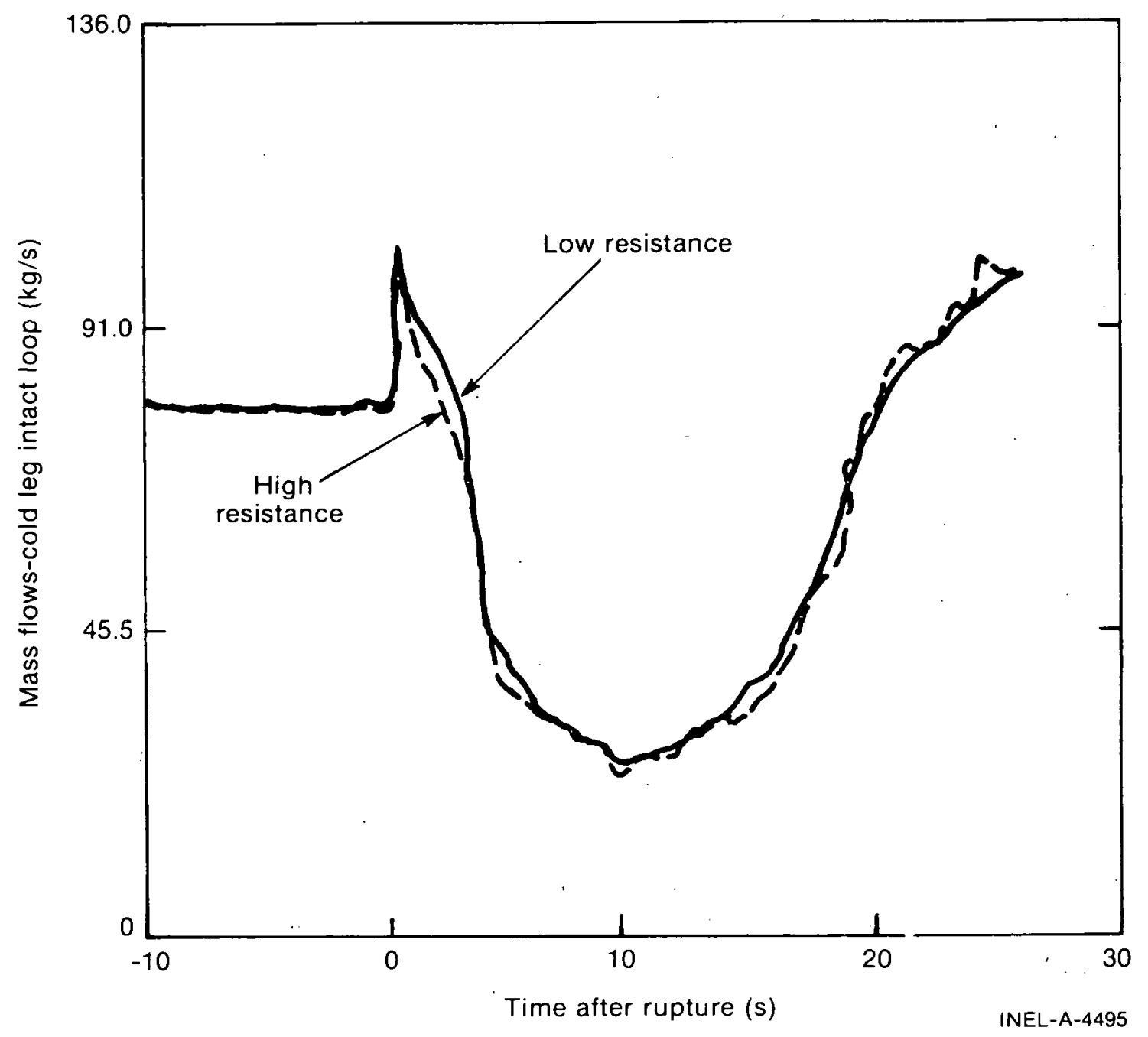

Fig. 21 Cold leg intact loop mass flow response -- Semiscale isothermal blowdown. 


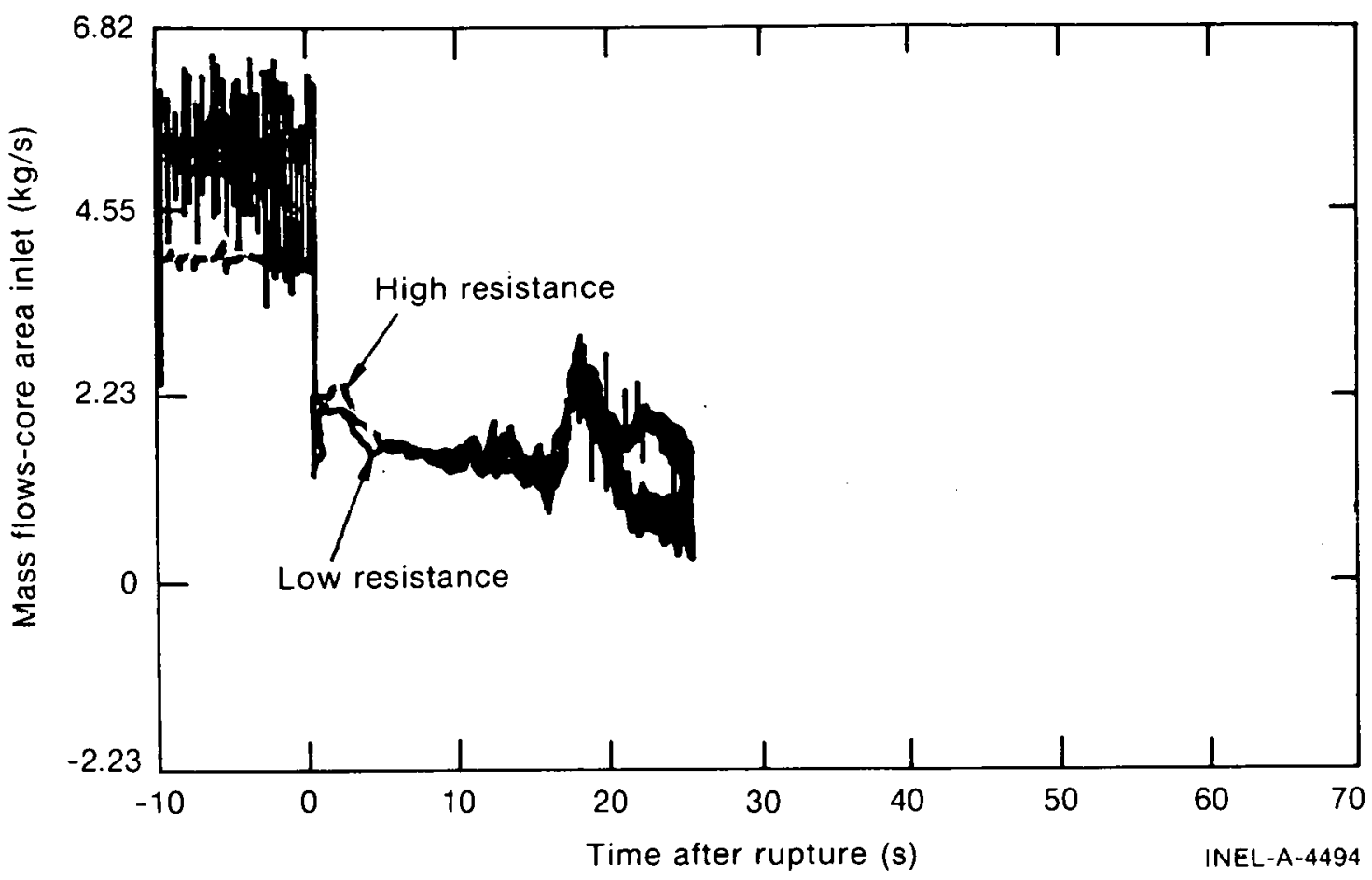

Fig. 22 Core inlet mass flow response -- Semiscale isothermal test.

Tesl S-03-7 was conducted with the initial conditions matched to the initial reflood conditions expected following the depressurization (blowdown) portion of a typical Semiscale MOD-1 integral test. The initial conditions and system configuration of Test $5-03-6$ and -7 were matched with the exception of the intact loop filow resistance being increased for Test $5-03-6$ by changing the orifice plate at the pump outlet.

The same procedure was followed in establishing the initial conditions before reflood initiation for each test: (a) the system pressure was established by controlling the pressure in the pressure suppression system, (b) the initial water level in the lower plenum was establișhed, (c) the core power was increased until the maximum specified power was attained and (d) the ECC injection was initiated when the maximum spectfled rod cladding temperature was attained. 


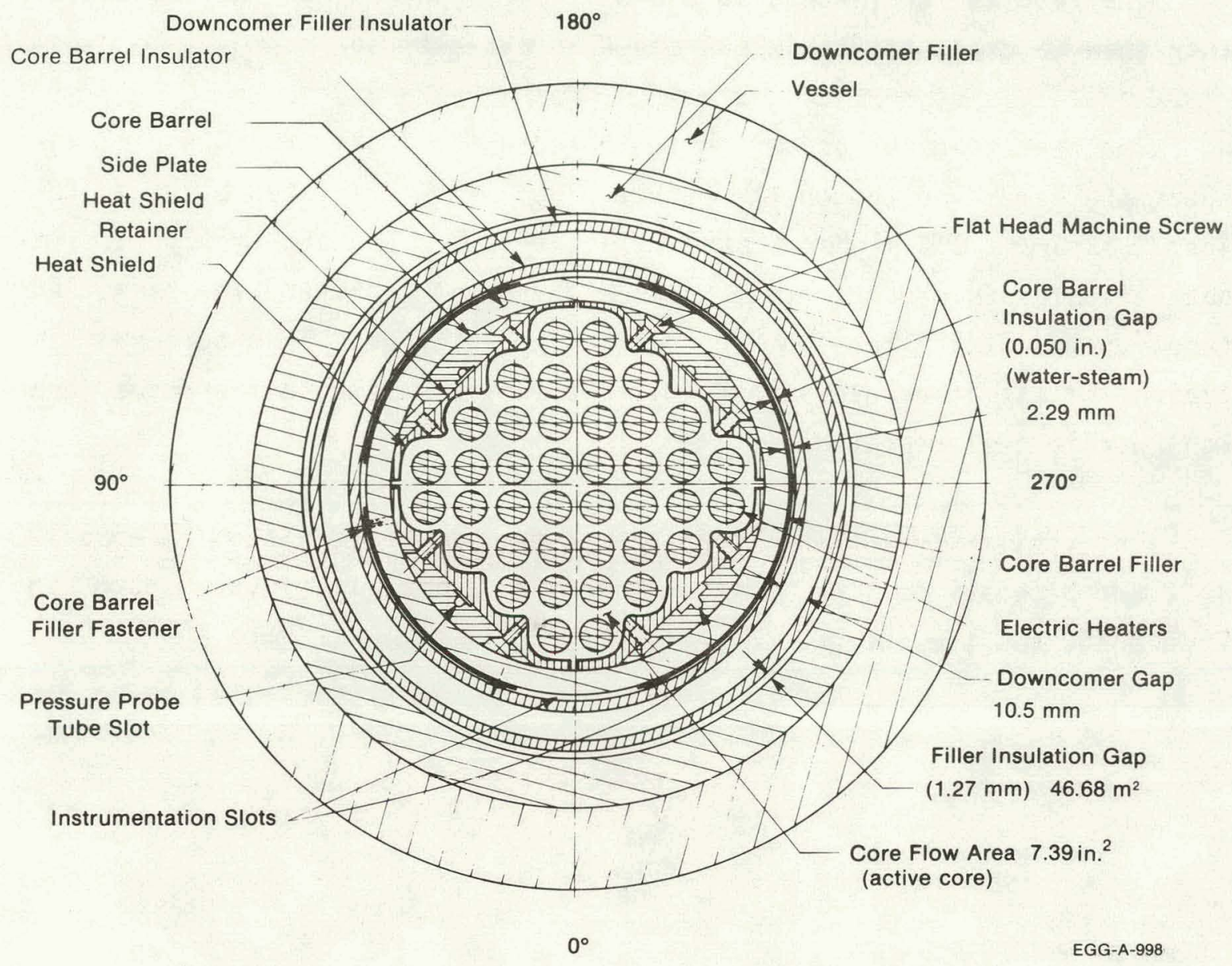

Fig. 23 Semiscale vessel cross section and core layout. 


\section{RESULTS OF SEMISCALE REFLOOD TESTING}

The results for Tests $5-03-6$ and -7 are reported in Reference 14; they show no great effect in the measured parameters.

The heat transfer occurring in the core for Tests s-03-6 and -7 was about the same even though the intact loop flow resistance used for Test s-03-6 was $80 \%$ higher than for Test $\mathrm{s}-03-7$. The similarity in core heat transfer is demonstrated by the agreement between the measured temperatures at the core hot spot shown in Figure 24. This agreement is typical of all other elevations in the core where the differences are well within test repeatability.

The similarity in heat transfer between Tests S-03-6 and -7 appears to occur because of the similarities in the core flow, shown in Figure 25, and the integrated mass entering the core (Figure 26). 


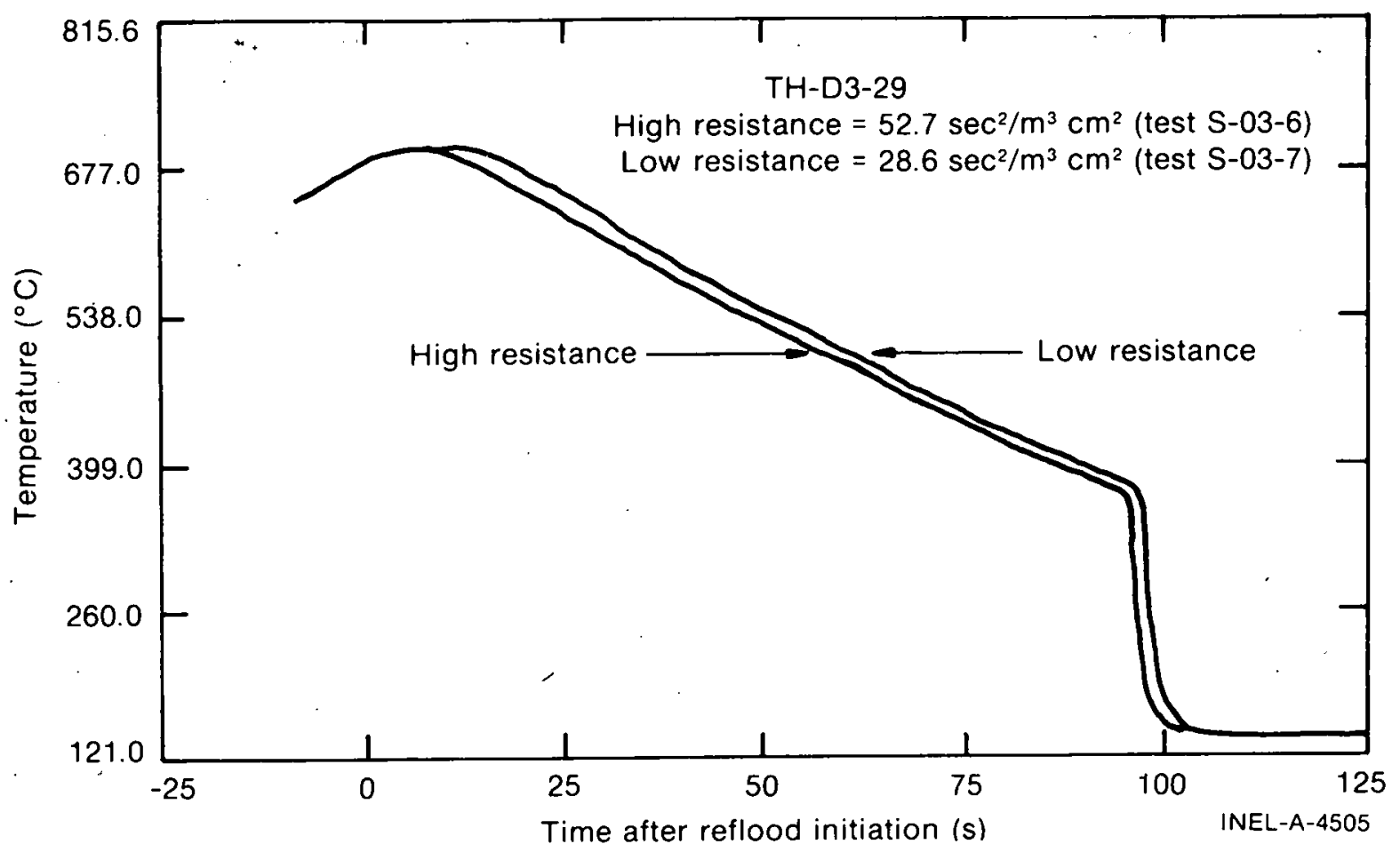

Fig. 24 Temperature response at the 29-in. elevation -- Semiscale REFLOOD tests.

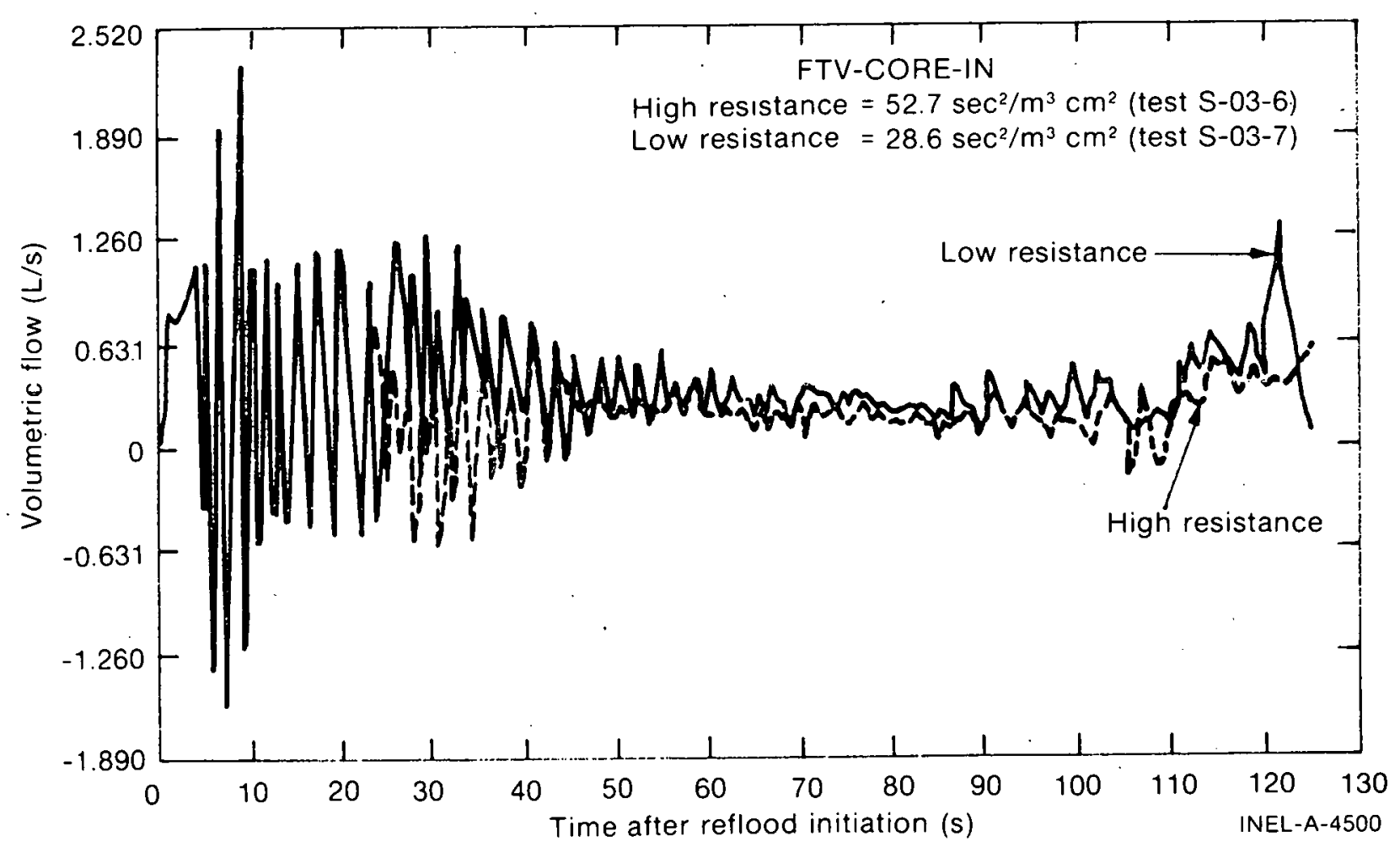

Fig. 25 Core inlet flooding rate -- Semiscale REFLOOD tests. 


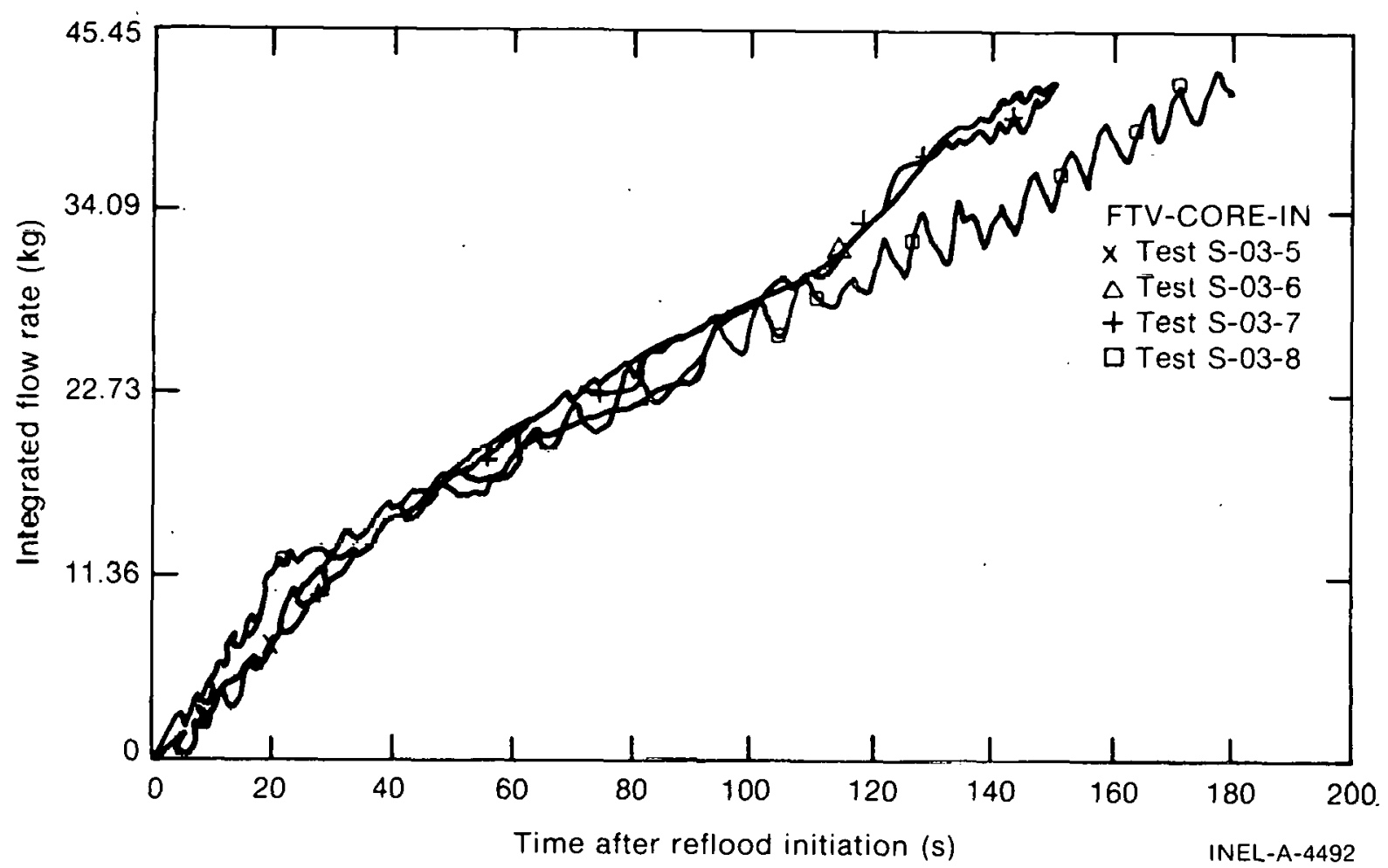

Fig. 26 Core inlet integrated mass flow rate -- Semiscale gravity REFLOOD tests.

\section{FLECHT-SET EXPERIMENT}

The full length element core heat transfer - separate effects test (FLECHT-SET) experiments Phase $B^{[15]}$ had as an objective the determination of lhe influerice of the intact loop hydraulic resistance on reflooding thermal hydraulic phenomena.

The FIECHT-SET facility, designed to simulate the primary coolant system of a PWR, did not provide simulation of the containment or auxiliary systems. The facility consists of 100 full length (same as a PWR) electrically-powered rods in a bundle, two PWR length coolant loops, each with active steam generator, and a PWR length downcomer, which wás a tube separate from the vessel. The ANS $+20 \%$ power decay curve for the rod bundle, was programmed to begin when the water reached the bottom of the heated length. 


\subsection{Results of FLECHT-SET REFLOOD Experiments}

The results of FLECHT-SET experiments are reported in References 15 and 16. To determine the effect of intact loop resistance, the results of Experiments 1708B, 1809A, 2714B, and 3215B are compared.

In run 3215B both broken and intact loops resistances were increased by 25\%. Run 2714B was a base case. The results of these two tests are compared as follows.

\begin{tabular}{|c|c|c|c|c|c|}
\hline $\begin{array}{c}\text { Run } \\
\text { Number } \\
\end{array}$ & $R^{\prime}$ & $\begin{array}{c}T_{\max } \\
\varrho 1.83 \mathrm{~m}\left({ }^{\circ} \mathrm{C}\right) \\
\end{array}$ & $\begin{array}{l}t \text { turn around } \\
01.83 \mathrm{~m}(\mathrm{~s})\end{array}$ & $\begin{array}{l}t \text { quench } \\
\text { @ } 1.33 \mathrm{~m} \mathrm{(s)}\end{array}$ & $\begin{array}{l}t \text { :bundle } \\
\text { quench (s) }\end{array}$ \\
\hline $3215 B$ & $\begin{array}{l}1.25 x \\
\text { normal }\end{array}$ & 791 & 95 & 301 & .591 \\
\hline $.2714 \mathrm{~B}$ & normal & 744.4 & 99 & 274 & 531 \\
\hline Change & & $75.5^{\circ} \mathrm{C}$ & $-4 s$ & $27 \mathrm{~s}$ & $30 \mathrm{~s}$ \\
\hline
\end{tabular}

The effect of increasing flow resistance in both the broken and the intact loops is to increase the maximum temperature, decrease the turn around time slightly, and increase the quench time, due to lower flooding rate for the high resistance test ${ }^{[16]}$.

Run $1708 \mathrm{~B}$ was for $1.25 \times$ normal resistance and run $1809 \mathrm{~B}$ was for $.1 .25 \times$ normal resistance in the broken loop only. In 1708B the effects of condensation as the downcomer overflowed were observed. The condensation effects observed were lower flooding rate and consequently longer time to quench. The comparison of $1708 \mathrm{~B}$ and $1809 \mathrm{~B}$ below show almost no difference in

\begin{tabular}{|c|c|c|c|c|c|}
\hline $\begin{array}{l}\text { Run } \\
\text { Number }\end{array}$ & $R^{\prime}$ & $\begin{array}{c}\mathrm{T}_{\max } \\
0.1 .83^{\mathrm{m}}\left({ }^{\circ} \mathrm{C}\right)\end{array}$ & $\begin{array}{l}\mathrm{t} \text { turn around } \\
01.83 \mathrm{~m}(\mathrm{~s})\end{array}$ & $\begin{array}{c}t . \text { quench } \\
0.1 .83 \mathrm{~m}(\mathrm{~s}) \\
\end{array}$ & $\begin{array}{l}t \text { bundle } \\
\text { quench (s) }\end{array}$ \\
\hline $1708 \mathrm{~B}$ & $\begin{array}{l}\text { 1.25 R' } \\
\text { both loops }\end{array}$ & 656 & 12 & 90 & 165 \\
\hline $1809 \mathrm{~B}$ & $\begin{array}{l}1.25 R^{\prime} \\
\text { broken } \\
\text { loop only }\end{array}$ & 650 & 12 & 88 & 135 \\
\hline
\end{tabular}


time to quench the hot spot, or time for turn around. The conclusion which may be drawn is that increasing the intact loop resistance has little effect ( $1 \%$ in maximum temperature and $2 \%$ in hot spot quench time). Although Reference 16 draws no precise conclusion about the effect (from tests with $15 \%$ power difference and $3 \%$ housing initial temperature difference), it infers that broken loop resistance has little effect on reflood.

Certainiy, the effect of resistance is small and occurs at a time late in reflood when it is not of major significance. 


\section{CONCLUSIONS}

The results of experiments in LOFT, Semiscale, and FLECHT-SET together with analyses with RELAP4, FRAP-T2, and FLOOD4 have been reviewed for effects of intact loop hydraulic resistance variation. These data and analyses have shown that there is no effect on blowdown characteristics and small effects on the reflooding characteristics. It should be noted that the available blowdown experiments are isothermal and do not provide information on the interactions which may take place in a hot core. However, the blowdown calculations do include a hot core and also show no great effect.

The conclusion is that for the purposes of simulating a LPWR the intact loop hydraulic resistance can be core area scaled without adverse effect. 


\section{REFERENCES}

1. L. J. Ybarrondo, et al, "Examination of LOFT Scaling", ASME Winter Annual Meeting, New York, NY, November 17-22, 1974, 74-WA/HT-53.

2. G. L. Singer, et al, RELAP4/MOD5 - A Computer Program for Transient Thermal-Hydraulic Analysis of Nuclear Reactors and Related Systems - Users Manual, Volume 1, ANCR-NUREG-1335 (September 1976).

3. J. A. Dearien, ct a1, FRAP-T2 - A Computer Code for the Transient Analys is of Oxide Fuel Rods, Volume I, FRAP-T2 Analytical Models and Input Manual, TREE-NUREG-1040 (March 1977).

4. G. E. McCreery, et al, Thermal-Hydraulic Analysis of the Semiscale Mod-1 Reflood Test Series (Gravity Feed Tests), TREE-NUREG-1010 (January 1977).

5. H. C. Rubiusull, LOFT System and Test Description (Loss-of-Coolant Experiments Using a Core Simulator), TREE-NUREG $=1019$ (Nüvember 1976).

6. T. K. Samuels, Conformed Copy of LOFT Experiment Operating Specification for Nonnuclear Test Series L1, Experiment 3, Volume 2, ANC, EOS Volume 2, NNE L1-2, Revision 0 (July 1975).

7. T. K. Samuels, Conformed Copy of LOFT Expriment Operating Specification, Volume 2, Nonnuclear Test Series L1, Experiments 3 and $3 A$, NNE $L 1-3$ and $3 A$. ANC, EOS Volume 2, NNE $L 1-3$ and $3 A$, Revision 2 . (September 1976).

8. H. C. Robinson, Experiment Data Report for LOFT Nonnuclear Test L1-2, TREE-NUREG-1026 (January 1977). 
9. J. R. Chappel, Quick Look Report on Loss-of-Coolant Experiment L1-3, ANC, QLR-74-4 (JuTy 1976).

10. G. M. Millar, Experiment Data Report for LOFT Nonnuclear Test L1-3A, TREE-NUREG-1027 (December 1976).

11. E. M. Feldman, Semiscale Mod-1 Program and System Description for the Reflood Heat Transfer Test (Test Series 3), ANCR-NUREG-1305 (May 1976).

12. S. N. Zender, Experiment Data Report for Semiscale Mod-1 Test S-01-2 Isothermal Blowdown with Core Resistance Simulator, ANCR-1194 (February 1975).

13. S. N. Zender, Experiment Data Report for Semiscale Mod-1 Test S-01-3 (Isothermal Blowdown with Core Resistance Simulator), ANCR-119.5 (March 1975).

14. H. S. Crapo, Experiment Data Report for Semsicale Mod-1 Tes.ts S-03-5, S-03-6, S-03-7, and S-03-8 (Reftood Heat Transfer Tests.), ANCR-NUREG-1308 (June 1976).

15. J. P. Waring, E. R. Rosal, L. E. Hochreiter, PWR FLECHT-SET Phase B1 Data Report, WCAP-8431 (December 1974).

16. J. P. Waring, L. E. Hochreiter, PWR FLECHT-SET Phase Bl Evaluation, WCAP-8583 (August 1975). 
DISTRIBUTION RECORD FOR TREE-NUREG-1165

Internal Distribution

1 - Chicago Patent Group 9800 South Cass Avenue Argonne, Illinois 60439

2 - C. A. Benson Idaho Operations Office-DOE Idaho Falls, ID 83401

3 - R. J. Beers, ID

4 - P. E. Litteneker, ID

5 - R. E. Tiller, ID

6 - R. E. Wood, ID

7 - H. P. Pearson, Supervisor Technical Information

8-17 - INEL Technical Library

18-37 - Authors

38-47 - Special Internal

Fxtcrnal Distribution

48-49 - Saul Levine, Director Office of Nuclear Regulatory Research

Washington, D. C. 20555

50-354 - Distribution under NRC-2, Water Reaclor Safety Research Systems Engineering 